\title{
Old Money-The History of Giving in Asia
}

\author{
Heesu Jang
}

In 2010, Warren Buffett and Bill Gates visited China to convince their Chinese millionaire and billionaire counterparts to commit to giving large portions of their wealth to charity. During this time, the Western media's portrayal of the philanthropic landscape in China, such as that by The Associated Press, was that it was "relatively immature." Journals readily noted that while China's GDP has recently come to reach half of America's, the United States philanthropic market was still 21 times larger. ${ }^{1}$

Like China, other Asian economies are frequently subject to similar news coverage whenever prominent Western businessmen pay visits to promote philanthropy throughout the region. While it celebrates its Gates, Ford, Carnegie, and Rockefeller families as generous and selfless champions of philanthropy, it calls for greater action from Asia as a whole.

Admittedly, Asia is outnumbered, outweighed, and outscored by the West on most fronts within the charitable sector. The West in general boasts more philanthropists, more individual donors, and more organizations, not to mention the sheer amount and scope of donations. Nevertheless, contrary to the claims of the media, the clear superiority of the West in these measures does not dictate Asia's capacity for doing good.

To better make sense of this apples-to-oranges comparison between Asian and Western philanthropy, one must first revisit the difference and

H. Jang

CAPS, Hong Kong SAR, China

(C) The Author(s) 2018

R.A. Shapiro et al., Pragmatic Philanthropy, https://doi.org/10.1007/978-981-10-7119-5_2 
the relationship between charity and philanthropy defined by the first chapter of this book: philanthropy is a formalized and systematic process of doing good, while charity is the act of doing good itself. That is, even though philanthropy in Asia may be "relatively immature" due to the continent's rather late economic growth and exposure to the concept, history tells us Asians, too, know how to be charitable and generous.

Four key historical experiences are shared by most, if not all, Asian economies. First, Asians emphasize caring for the well-being of fellow community members, from family to locality. Second, religions significantly influence the giving and helping behaviors and patterns of Asian countries and peoples, with many religious institutions even going so far as to deliver social services to the people. Third, modern civil society in most Asian countries flourished as either a challenging force against, or as a direct result of, twentieth-century colonialism. Finally, the public image and personality of modern civil society in Asia has been shaped by past interactions and experiences with powerful central governments. This chapter will explore in greater detail these themes of community, faith, colonialism, and authoritarianism for each of the 11 Asian economies, to demonstrate how Asia's long history of generosity and charity will help pave way for a philanthropic tomorrow.

\section{INDIA}

Socioeconomic incongruities coexist in India. Considered one of the leading developing countries in terms of annual GDP growth, India still suffers from nationwide poverty. One in five Indians is poor, and an estimated 270 million citizens live below the poverty line. ${ }^{2}$ Basic sanitation, health care, education, and other social services are not readily available to much of the local population.

Accompanying some of these alarming challenges are promising trends. India is renowned for its advanced information technology sector, as well as for housing major homegrown multinational corporations across various industries. It boasts more than 100 billionaires, consistently ranking India in the top five with the likes of the United States, China, and Germany. ${ }^{3}$ And it is the largest democracy in the world.

India's philanthropy reflects such contrasts. With socioeconomic hardships alongside a dynamic marketplace full of new wealth, the gap for Indian charity and philanthropy to tap into is glaringly apparent.

Preceding this present-day environment favorable for charitable individuals and institutions is a rich track record of giving-both informal and formal-that predated even the pioneers in American philanthropic history. 
From the late nineteenth century to the early twentieth century, India for the first time witnessed the establishment of modern foundations by prominent members of the private sector, including the J. N. Tata Endowment Scheme (1892) and the N. M. Wadia Foundation (1909). ${ }^{4}$

India also possesses a deeply ingrained culture of informal giving. ${ }^{5}$ Providing financial and non-financial support to one's immediate family and community (caste, village, or other extended social groups) is common. This culture resonates across the country today: 24 percent of donors reported having given money to their friends, neighbors, and colleagues, while 53 percent of donors indicated that an unreturned loan to a family relative is a donation. ${ }^{6}$ Families also provided various social services to their domestic helpers in addition to their paid salary. Clothing and food were common donations, along with financial contributions to their health care and their children's education.

Finally, donating for religious purposes has historically been a major part of Indian giving. In fact, charitable religious endowments and trusts came before modern philanthropic institutions. Donations frequently went to Islamic endowments specifically for charitable purposes, known as waqfs, and to trusts like the Tirumala Tirupati Devasthanams that managed Hindu temples and provided social services such as schools and hospitals. India's organic institutionalization of philanthropy and long culture of family, community, and religious giving attest to the country's preexisting familiarity with and maturity in doing good.

This homegrown charity and philanthropy reflects India's strong faithbased textual roots to its generous culture. Hinduism-the most widespread religion in India today-Buddhism and Islam all contribute to Indians' inclination to do good. The concepts of zakat (almsgiving) and sadaqaat (voluntary offerings) in Islam and of bhiksha (food given as alms) and avoiding bad karma in Buddhism particularly pertain to giving. ${ }^{7}$

In Hinduism, many ancient Sanskrit texts are comprised of extremely detailed stipulations about charity and philanthropy. ${ }^{8}$ That is, beyond simply encouraging benevolent actions, these sources spell out the who, what, when, why, and how of daana (giving) and seva (service). Kings were also required by the epic of Mahabharata to share their wealth with the people and not use it for their own pleasure. Sanskrit books even imply a hierarchy, as in the Laws of Manu, in which food, required by all beings for their survival, emerges as the best in worth over gold, silver, salt, and so on. A benefactor's attitude had to be genuine and passionate; certain traits were also expected of the beneficiary. In other words, giving merely for the sake of giving is insufficient, necessitating benefactors to check multiple boxes to give, strategically and efficiently. 
Still, India has not been immune to external influence on its charitable and philanthropic sector. Industrialization during the British Raj era increased both the size and the scope of philanthropy in India. ${ }^{9}$ With a modernized economy, the overall wealth of businesses exceeded an unprecedented amount, resulting in a bigger surplus for public welfare. At the same time, industrialization helped expand the market coverage of businesses and allowed them to operate beyond the regional confines of their respective headquarter cities, which in turn scaled up the scope of the private sector's philanthropic activities. Many domestic philanthropic foundations reflect India's inherent culture and history of goodwill, but they grew against the backdrop of industrialization that occurred under British colonial rule.

India's government played an important role. As early as 1860, India legally recognized the existence of nonprofit groups via the British Raj Societies Registration Act, granting the status of a "society" to a group of seven or more people in any literary, scientific, or charitable association. ${ }^{10}$ Numerous nonprofit organizations and philanthropic foundations arose as a result, and this piece of legislation still applies to NGOs today. ${ }^{11}$

The legacy of the colonial era also shaped philanthropic thought. As many donors concluded that British dominance grew from advanced science and technology, philanthropists changed their giving priorities, funneling more money into relevant endeavors, as well as into projects of social reform. ${ }^{12}$ More money was funneled into secular purposes, such as social reform and cultural revivalism projects. In the end, with Mahatma Gandhi's return to India in 1916, this particular evolution of Indian philanthropy culminated in a mobilized Indian civil society's involvement in the independence movement.

Gandhi's return in 1916 shifted the course of India's development plan to economic self-sufficiency. As part of this quest for self-sufficiency, voluntary action at the local village level became pivotal in the drive to tackle widespread poverty. ${ }^{13}$ As a result, the number of village-oriented community organizations proliferated. ${ }^{14}$ Gandhi's theory of trusteeship inspired many wealthy individuals at the time to donate money and resources for the good of the greater community, whether it would be for the independence movement or for the delivery of social services. ${ }^{15}$ In so doing, Gandhi utilized many of the Hindu concepts relevant to charity and philanthropy in a way that transcended the terms' original definitions to bring about greater change in line with his goals. ${ }^{16} \mathrm{He}$ worked to transform the primary motive behind doing good from acquiring merit as a religious 
obligation to wholeheartedly wanting to contribute to the general welfare of all, stating, "You should regard yourself as the trustees and servants of the poor. Your commerce must be regulated for the benefit of the toiling millions and you must be satisfied with earning an honest penny." 17

Gandhi also said, "Earn your crores by all means. But understand that your wealth is not yours; it belongs to the people. Take what you require for your legitimate needs, and use the remainder for society." 18 The Birla and Bajaj families were notably affected by the principles and theories of Gandhi and donated millions of rupees for causes that he promoted. ${ }^{19}$

Post-independence India (1948-1980s) further encouraged philanthropy. The socialist, interventionist government focused on social welfare and economic development, with a heavy dose of central planning. ${ }^{20,21}$ The private sector supported the government's developmental agenda, and India experienced a dramatic increase in the number of private trusts and foundations. ${ }^{22}$ The government, in turn, encouraged citizens' participation in social welfare programs, but some argue that the state's dominant role actually imposed limitations on the nonprofit sector, so that it was only the confrontational response to inefficient government that led to the burgeoning of the nonprofit sector in India. ${ }^{23}$ Be that as it may, the outcome of growth in both philanthropy and charity in India is unquestionable.

Today, the charitable and philanthropic sector of India is one of the most vibrant in the world. Individual giving in India is a global outlier, trumping the rest of the world at its level of GDP per capita. ${ }^{24}$ More than 2 million NGOs are reported to be active in the country, while the numbers of philanthropists and potential philanthropists in millionaires and billionaires are increasing every year. ${ }^{25,26}$ The Companies Act of 2013 and its 2-percent corporate social responsibility spending requirement has had a huge impact, as will be seen in greater detail in a later chapter of this book. But the socioeconomic shortcomings, discussed in the beginning of this section, persist to plague the country, making the role of charity and philanthropy all the more imperative for the future trajectory of India.

\section{Philippines}

In the Philippines, we see the impact of all four themes: community, faith, colonialism, and authoritarianism. The Filipino lexicon reflects its deep cultural roots in traditions of pakikipagkapwa, a sense of shared community and kapwa, compassion. To this day, Catholicism plays a crucial role 
both in spiritually encouraging charity, as well as in directly providing basic social services to those in need. Two colonial regimes-Spanish and American-helped establish the initial infrastructure needed for its now vibrant civil society and philanthropic community, while the Marcos dictatorship cracked down heavily on advocacy groups, ultimately triggering a fierce counteraction from an extremely well-mobilized nonprofit sector.

In pre-colonial times, informal mechanisms of mutual self-help volunteerism prevailed throughout the country at the village level. Volunteers often helped with construction of public infrastructure projects such as churches, schoolhouses, streets, plazas, and cemeteries. ${ }^{27}$ In fact, this domestically bred practice of bayanihan (assuming another's burdens) was more commonplace than religious associations exported by Catholicism and Spanish colonialism. ${ }^{28}$ This unique history of alleviating fellow community members' hardships demonstrates the Filipinos' deeply ingrained fondness for community welfare, manifested in both the language and village-level volunteerism.

Under Spanish colonialism, the Philippines began to see for the first time the establishment of formal charitable organizations. Public goods institutions set up by the Roman Catholic Church left behind a significant legacy of introducing institutionalized social delivery organizations (SDOs), alongside individual philanthropic giving to the Church. ${ }^{29}$ With its funds, the church built hospitals and orphanages, and its cofradias (brotherhoods) were instrumental in the provision of welfare services to the poor and needy. Not only did these religious associations fulfill their basic duties of arranging town festivals in honor of saints and ensuring the observance of Christian morals, but they also behaved like charitable groups by providing free labor and money to their immediate communities in times of crisis. ${ }^{30,31}$ In addition to these charitable and social imports, Catholic missionaries appended the Western notion of kawanggawa (charity) to the Filipino dictionary of doing good. ${ }^{32}$

The American colonial government further facilitated the progression of Philippine civil society in its resemblance to contemporary nonprofit organizations and foundations. Under the Americans, secularism flourished, demarcating boundaries between state and church, as well as between state and non-governmental provision of public goods and services. ${ }^{33,34}$ As a result, the Philippines witnessed the emergence of secular welfare agencies, interest groups, professional associations, and charitable institutions. During this period youth, labor, peasant, and women's organizations flourished, alongside the creation of professional groups such as 
the Philippine Medical Association and the Philippine Bar Association. ${ }^{35}$ More sophisticated, larger organizations with written constitutions-such as the Society of the Poor-also came into being. ${ }^{36}$ Furthermore, Americans brought over to the Philippines their own non-government organizations like the American Red Cross and the Anti-Tuberculosis Society, which were known to receive philanthropic support from the local elite. ${ }^{37,38}$ The Philippine Corporation Law of 1906 further encouraged nonprofit groups by giving them legal recognition along with proactive government funding (2.2 percent of the government's annual expenditure at the time) for local associations that focused on health services. ${ }^{39}$

In the 1960s and 1970s, the hopelessly deteriorating economy and increasingly rampant corruption of the Marcos regime triggered the mobilization of numerous social movements across sectors, from students to human rights advocacy. ${ }^{40}$ Eventually, these movements gradually evolved into formal non-governmental organizations, supplementing the lack of government presence in delivering essential social services in certain areas of the country. ${ }^{41,42}$ With these trends, civil society in the Philippines took its unified shape for the first time via protest and calls for reform against the authoritarian Marcos government. Marcos responded in 1972 with martial law, until public protests finally ousted him from power in 1986.

The subsequent Corazon Aquino administration enacted legislation favorable to nonprofits. The 1987 constitution explicitly stipulates the rights of non-governmental organizations, so that the state must respect their participation. With this new legal framework, registered NGOs rose by an astonishing 96 percent in less than a year, from 27,100 in early 1986 to 53,000 by late September. ${ }^{43}$ And as José Magadia points out, civil society in the Philippines changed its focal orientation from resistant advocacy to a variety of other issues primarily in social services. With this shift in its fundamental identity, the overall sector was able to grow further by incorporating additional functions such as policy research, network building, and so forth. ${ }^{44}$

Income inequality, poverty, corruption, and ineffective public policy still plague the Philippines. In multiple socioeconomic indices and measurements, the country fares poorly, generally situating at the bottom half and lower tier. On the Social Progress Index, which attempts to capture how well countries provide basic social and environmental needs of their citizens, the Philippines ranks 68th out of 133 countries-even below its neighboring Southeast Asian nations of Malaysia and Thailand..$^{45}$ On the latest Corruption Perceptions Index, the Philippines ranks 95th out of 
168 countries, scoring behind the likes of China, India, Indonesia, Malaysia, and Thailand. ${ }^{46}$ Nevertheless, the fact that the Philippines hosts the largest number of NGOs per capita in Asia, between a quarter and half a million groups in total, reflects centuries of cultured yearning for doing good-and for civic engagement as a positive opportunity for the future.

\section{SOUTH KoreA}

Many observers say that modern Korean civil society began 20 years ago, in the aftermath of twentieth-century industrialization and democratization. Industrialization came first (the "Han River Miracle," after World War II), then, in 1987, the June Democratic Uprising against military governments shaped the state and society that followed. ${ }^{47}$

But the practice of doing good, and its institutionalized forms in civil society, long predated these events in Korea. Many such practices began with Confucianism, which has contributed enormously to present-day Korean culture, perhaps more so than in any other Asian community. ${ }^{48}$ As far back as the sixteenth century, Confucianism in Korea gave birth to private academies that taught ethics. These academies were essentially the equivalent of a modern-day NGO. They grew locally without any involvement and support from the state, instead funded through donations from local elites. ${ }^{49}$ And they demonstrated a high level of management autonomy and independence from the state. For example, the academies faced no interference from the government, neither in regulating their student admission policies nor in their economic plans to rent their lands to tenant farmers for self-funding. ${ }^{50}$ Unfortunately, tight oversight of these academies arrived under King Yeongjo in the eighteenth century, in the name of accomplishing "grand harmony," ultimately stalling the growth of this premature sector of society. ${ }^{51}$

Japanese colonialism had mixed effects on Korean civil society. Indirectly, it encouraged modern development, ending Korea's feudal society and introducing capitalism. ${ }^{52}$ It was also during this period that Korea had its first private scholarship foundation, Yangyounghoe, established in 1939. ${ }^{53}$ But Japan's aim to solidify control over the Korean peninsula involved cracking down on any form of social movements that challenged its colonial rule. ${ }^{54,55}$ Due to the hostile relationship between the colonial ruler and the Korean people, Koreans began to regard the regime more as an illegitimate alien power than as a moral patriarch like their past imperial rulers. ${ }^{56}$ This antagonistic anti-state orientation is constantly echoed throughout 
much of Korea's history during the twentieth century and defines the fundamental identity of Korean civil society to this day.

Independence from Japanese colonialism in 1945 enabled the brief growth of previously repressed social movements. Farmers, the poor, and other marginalized groups of society eventually congregated under an umbrella organization named Chonnong whose membership reached 3 million people in $1946 .{ }^{57}$ Service-oriented religious groups and charity were also for the first time introduced to the country during this period. ${ }^{58}$ This sudden expansion of civil society in Korea can be attributed to the lack of an official government for three weeks after liberation, which provided room for a high degree of freedom and autonomy that these movements had never experienced during the colonial era. ${ }^{59,60}$ However, this brief period of optimism for the charitable sector was cut short by the arrival of the first authoritarian ruler in modern Korean history, followed by a series of subsequent military dictatorships.

Three extremely powerful rulers dominated the next 40 years of the post-liberation Republic of Korea: Rhee Syngman (1948-1960), Park Chung-hee (1963-1979), and Chun Doo-hwan (1980-1988). Korean civil society's anti-state disposition further intensified under their rule, chafing against the military support that kept the presidents in power. ${ }^{61}$ This confrontational relationship meant advocacy groups, serving as the representative voice of the disgruntled citizenry, came to lead the nonprofit sector in Korea. ${ }^{62,63}$

Even so, other kinds of social service organizations managed to flourish amid the tensions. Under President Rhee Syngman, non-political serviceoriented organizations backed by foreign aid were relatively free to pursue their welfare activities. After the coup that installed President Park Chunghee, Korea saw a rise in the standard of living, as Park's regime was both authoritarian and development-oriented. The resulting growth of the middle class enabled the development of such organizations as the Saemaul (New Village) Movement. Now regarded as one of the most well-known legacies of the Park regime, the New Village Movement played a huge role in the urbanization and development of Korean local agricultural communities, implementing the central government's policies and plans at a grassroots level. ${ }^{64}$ Completely rehabilitating rural infrastructure from top to bottom, the New Village Movement is now considered a "classic example of community-driven development." ${ }^{65}$

Park's development-driven agenda came to fruition under his successor Chun Doo-hwan, another military dictator, in the 1980s. That decade 
brought rapid industrialization, urbanization, and socioeconomic class diversification, which in turn led to popular support for various civil society organizations (from women's groups to environmental advocacy groups). Such organizations played active roles in anti-state efforts to bring down the military dictator, until Chun eventually stepped down in the face of ongoing public demonstrations and protests. ${ }^{66}$

Those 40 years of authoritarianism shaped the advocacy-focused, antistate nature of Korean civil society. Even today, the most influential and prominent organizations are advocacy groups concerned with issues such as the environment, women's rights, and social justice. ${ }^{67}$ Now there are 7600 such organizations, the majority of which were founded in the 1990s. And, in the words of Bidet, authoritarian governments' "instrumentalization" of non-governmental organizations and civil society groups whose activities and projects were well in line with their policy objectives also laid the foundation for various SDOs and the overall nonprofit sector.

That legacy also presents Korea with particular challenges. Donors recognize Korean civil society's heavy sway toward advocacy groups, and that makes some wary; many philanthropists (usually chaebol, the Korean term for family dominated conglomerates) are reluctant to donate their money to charity and partner with local NGOs, alternatively seeking to work by themselves via private foundations or to work together with the government. ${ }^{68}$ This distrust is not one-sided. Because Korea's wealthy elite traditionally maintained close ties with military regimes, their lack of civic participation against authoritarianism makes them remnants of authoritarianism. The recent scandal of Korean conglomerates' shady donations to former President Park Geun-hye has reaffirmed this suspicion of Korean society against the wealthy, exacerbating distrust between the people and potential philanthropists.

\section{CHINA}

China's development of charity and philanthropy is often misconstrued to be anemic. With its one-party political system and a widespread assumption that civil society is inherently a Western value and concept, this is understandable. Before the current Communist Party rule, the Chinese moved from one imperial regime to another, casting shadow over a rich culture of self-help. But China has a long history of doing good.

Confucianism introduced China to basic concepts of community care, from taking care of the elderly to providing education to the youth. This 
provision of welfare predated any formal institutionalization of social welfare and civil society, but it was to be taken up primarily by the government acting as the father figure of the people. ${ }^{69}$ But the officials of the Qin dynasty disagreed. They advocated for a strong state and a weak society, neglecting the state's civic duty to attend to the poor, believing that those in need were at fault for their own poverty. Chinese citizenry stepped forward to fill this gap, creating the country's first systematic private form of charity: family-based kinship organizations. These family self-help groups were both a reaction to the legalist Qin regime that failed to provide social services and a reflection of existing Confucian principles that emphasized community care in terms of family relations.

These lineage organizations provided public goods and services, including care for widows and orphans, distribution of grain, and construction of schools. ${ }^{70}$ Wealthy individuals - most notably, salt moguls—oversaw village social welfare activities. ${ }^{71}$ These clan-based groups gradually spread from just southeast coastal China to the rest of the country during the Song (960-1279) and Qing (1644-1912) dynasties. The nature of these groups also changed at the same time, easing their blood-tied membership requirements and focusing more on the delivery of social services. ${ }^{72}$ Family-based groups continued to flourish after the end of imperial dynasties, and other types of civic organizations arose, including professional associations and foundations. ${ }^{73}$

The smooth uptrend in China's growing civil society halted after the Communist Party came to power. The Communist Party cracked down on all private associations, seeing them as a sign of state failure. ${ }^{74}$ The repression of these organizations, along with late exposure to key concepts pertaining to charity, shaped current misconceptions of Chinese civil society.

Despite this unfriendly environment for the third sector, another term for civil society, during the twentieth century, Deng Xiaoping's open-door economic policies enabled the beginning of contemporary charity and philanthropy. In 1995, an NGO Forum held alongside the Fourth World Conference on Women in Beijing introduced the general public and the government to the term "NGO" for the first time. ${ }^{75}$ With this occasion, the Communist Party accepted that NGOs were not anti-governmental opposition groups.

NGOs and civil society ended up aligning well with Deng's free-market ideology. The growing popularity of a liberalized Chinese economy crept into the field of social services, applying free-market principles to social welfare and allowing room for the third sector to take up a much more 
influential role in delivering public goods and services to the people. Hence, during the second half of the 1990s, China experienced a huge surge in the number of large domestic charity organizations, such as Friends of Nature and Global Villages, as well as the entry of many foreign NGOs. ${ }^{76}$

Under the Hu Jintao government, charities faced a brief period of restrictions, as Beijing became wary of NGOs bringing forth ideologies challenging to the Communist Party. ${ }^{77}$ At this time, government-organized programs, such as the China Red Cross, rose to prominence and became dominant forces within the sector. ${ }^{78}$ The Chinese government also reverted to more involvement in the provision of social goods and services, ending various market initiatives begun in the 1990s.

Amidst this recent experience of government pushback, other challenges to the growth of Chinese philanthropy arose in the form of nationwide scandals and controversial legislations.

Most notable was the 2011 Guo Meimei scandal, in which a young Chinese woman who claimed to be the "commercial general manager" of the "China Red Cross Chamber of Commerce" flaunted her lavish lifestyle of luxury sports cars and branded bags on social media. It caused such public uproar that domestic charitable organizations saw a 90-percent drop in donations. ${ }^{79,80}$ This particular scandal exacerbated the lack of institutionalized trust in China, which heavily relies on guanxi (strong personal connections). ${ }^{81}$ The World Values Survey, for example, indicates that close to 80 percent of the Chinese respondents do not trust strangers. ${ }^{82}$ The Guo Meimei scandal further reduced the low level of institutionalized trust resulting from the culture of guanxi and societal distrust. Such scandals and their ramifications remain one of the biggest obstacles to the success of Chinese civil society.

The 2016 Charity Law put forth by the National People's Congress may shape the next set of relationships between the government and nonprofit organizations. Its impact is not yet clear. Supporters see improvements made in registration, fundraising, and tax incentives, while critics worry about restrictions on overseas NGOs. ${ }^{83,84,85,86}$ The Charity Law, its implications, and potential effects will be discussed in greater detail in a later chapter of this book.

China's long experience with charity and philanthropy brings context to the challenge given at the start of this section: yes, the United States boasts philanthropic giving 21 times larger than in China, with a GDP only twice as large, but that does not mean China is not interested in 
giving. ${ }^{87}$ China has a rich history of the wealthy giving back to society in the form of clan-based lineage organizations. Civil society proved resilient to a temporary downturn during the twentieth-century Communist rule and now is developing at a good pace. The following facts suggest an optimistic future: ${ }^{88,89,90}$

1. China has experienced a 66-percent increase in the total amount of charitable donations during the time span of 2009-2014.

2. Five times as many charitable organizations were in China by 2014, compared with ten years earlier.

3. Per capita charitable giving increased by 20 percent annually through 2013.

4. 2014 saw $\$ 15.51$ billion worth of total regular donations, even excluding one-off donations made for natural disasters.

\section{TAIWAN}

Modern Taiwan, founded after the Chinese Communist Party took full control of the Mainland in 1949, began as the Chinese Nationalist Partyor the Kuomintang (KMT)-fled to the island of Formosa. Prior to this KMT exodus, and before 50 years of Japanese colonialism, Taiwan was part of the Qing dynasty from 1683 to $1895 .{ }^{91}$ Under Qing influence, Taiwan gradually accustomed itself to Chinese cultural traditions, including Confucianism. Taiwan's culture of doing good long resembled that of Mainland China, while its recent state-civil society relations resembled that in South Korea due to the shared experience of having an authoritarian, developmental regime.

Yet Taiwan's culture is unique. It differs from its Mainland counterpart in the more significant role that Buddhism plays in charity and philanthropy. The Buddhist notions of karma and accumulating merit in particular galvanize the Taiwanese people to volunteer and donate. In multiple surveys, more than 50 percent of the respondents have directly attributed their motivation behind doing good to avoiding bad karma and accumulating merit. ${ }^{92,93}$ In fact, one of the most well-known and largest charitable institutions in Taiwan is a global Buddhist organization known as the Buddhist Compassion Relief Tzu Chi Foundation, the largest owner of private land in the country. ${ }^{94,95}$ This mix of Taiwan's Confucian roots and the widespread Buddhist faith and practices encouraging benevolent activities attests to Taiwan's societal capacity for doing good. Many believe that 
the Tzu Chi Foundation, whose assets are not publicly disclosed, is the wealthiest foundation in Asia.

Taiwan has also been shaped by military dictatorship for more than 30 years after 1947. This period, marked by rapid economic growth and industrialization, has been dubbed the "Taiwan Miracle." In the first half of this time, the KMT government solidified its control over the island, supervising and controlling the public arena with military might. Any demands or suggestions coming from society were met with suppression and censorship. Martial law put Taiwan under authoritarian rule for the next 38 years. Civil society became hard to imagine.

From 1963 to 1978 , economic policies started to top the list of priorities for the KMT. ${ }^{96}$ Shifting the economy to one based on export-oriented industrialization, the KMT inadvertently gave birth to and bolstered the urban middle and industrial working classes. For the first time, public life saw the influence of other societal interests-market forces-besides the military political party. However, the KMT still exercised its dominance, and many of the economic players displayed political loyalty to the KMT for business opportunities. ${ }^{97}$ Competing views of society were limited to a few intellectuals and social elites. ${ }^{98}$ Civil society remained in limbo.

In the 1980s, numerous social movements began to emerge, not as a unified opposition to the KMT but rather as a reflection of diverse interests and socioeconomic classes resulting from economic growth. ${ }^{99}$ Without this united front, and given the KMT's self-organized transition from "hard" authoritarianism to "soft" authoritarianism, co-opting the voices of Taiwanese civil society, Taiwan avoided the kind of direct confrontation seen in Korea's June Democratic Uprising of 1987. ${ }^{100,101}$ While Korea's military regime violently cracked down on dissident groups, the KMT in Taiwan eased toward democratization. ${ }^{102}$ With the co-opting of the third sector, social movements and civil society groups did not feel the necessity of confronting the government, but were instead inclined to engage with the state through formal mechanisms and channels set forth by the government.

This is not to say that there were no protests and public demonstrations against the government. In 1987, up to 1800 street demonstrations were recorded. ${ }^{103}$ As with Korea, authoritarianism amid a growing prosperity shaped civil society in Taiwan, so it began to be, and remains, advocacyoriented. On the other hand, the KMT's self-democratization led to a more constructive relationship between the state and the third sector, mutually reinforcing the democratization process and providing a much more favorable environment for the growth of the charitable sector in the country. 
This state-civil society cooperation reached its all-time high after the lifting of martial law in 1987. The Taiwanese government started to embrace and collaborate with these social movements, allowing formal establishment of NGOs. ${ }^{104}$ The third sector and the private sector began to be included as consultants in the legislation of policies, laws, and regulations. Furthermore, the nonprofit sector in Taiwan has taken an even more active role in its state-society relationship by engaging in foreign policy. In the context of Taiwan's unique cross-strait relations with China, Taiwan's Ministry of Foreign Affairs and civil society have cooperated with participation in international conferences. ${ }^{105}$ Nonprofit organizations are in effect acting to promote Taiwan's soft power abroad. With this friendly infrastructure and environment acquired after overcoming many historical obstacles, Taiwan now boasts nearly $60,000^{106}$ registered non-governmental organizations as of 2015, reflecting the growth and vibrancy of the sector.

\section{JAPAN}

Japan's civil society is an anomaly in the Asian continent. Japan as a nation is not well known for charity and philanthropy, despite its status as the most developed economy in the region. Frequently cited reasons range from the Japanese population's cultural disposition of deference to the state, and corporations to the developmental regime's tight regulatory and political oversight. ${ }^{107,108}$ These analyses of Japan's underdeveloped sector of doing good touch on material truths. What is missing in this discourse, however, is an acknowledgment of Japan's proven record, from ancient times to today, of helping others in the community.

Japanese philanthropy dates back to at least the seventh and eighth centuries, when members of the affluent noble class and high-ranking monks established charitable projects and institutions under major Buddhist temples such as the Tōdai-ji and Shitennō-ji. ${ }^{109}$ Buddhist temples initiated fundraising campaigns, known as Kanjin, to finance religious activities and social welfare initiatives. ${ }^{110}$ Catholicism, which arrived in Japan during the sixteenth century, further exposed the country to the concept of doing good. Catholic missionaries founded mutual aid organizations called Misericordia to raise funds for social service projects such as building nursing homes and leprosy hospitals. ${ }^{111,112}$

Homegrown Japanese philanthropy developed further in the Edo period (1603-1868). First, wealthy Osaka-based merchants established private academies backed by an endowment system, laying the grounds for 
Japan's modern-day foundations, zaidan hojin. ${ }^{113}$ Most notably, in 1829 , a purveyor to the feudal lord of Akita offered Kan-on-ko-land purchased for agricultural production whose proceeds went to assist local peasants and orphans. This philanthropic gesture, later joined by an additional 191 donors, exists to this day as a social welfare organization.

These cases of religious and institutionalized giving remained relatively isolated, however. Central authorities' long history of monopolizing the provision of public goods and social services left little room for civil society to grow beyond its beginning stage. ${ }^{114}$ The highly centralized public sector continued through the Meiji Restoration in the late nineteenth century. The Civil Code was established in 1898, legally recognizing and systematizing for the first time the existence of private nonprofit activities (the koeki hojin system). ${ }^{115}$ But the Meiji government's successful import of Western technology and culture into Japanese society provided the foundation of a modernized state. Japan then rose as a major imperial power in Asia, flexing economic and military dominance throughout the region from the 1920s to the 1940s. During this period of military authoritarianism, all private entities were merged into one single national organization under government pressure and supervision. ${ }^{116}$

After Japan's defeat in World War II, the war-torn island, faced with the challenge to quickly recover the economy, employed heavy central planning executed by its elite bureaucracy. This interventionist developmental state and its influential bureaucracy are key to explaining the current perception of Japanese civil society.

The developmental state imposed legal restrictions and encroaching managerial oversight on the nonprofit sector. The Civil Code covering each koeki hojin (public interest corporation) requires that an applying organization have its license granted by a government agency, contradicting the "non-governmental" part of NGOs. ${ }^{117}$ The application process is difficult and complex, with many facets advancing the government's agenda. For example, NGOs were made accountable to the practice of amakudari (translated literally as "descent from heaven"), pressuring NGOs to hire retired bureaucrats. ${ }^{118}$ Persistent requests for detailed accounts and activity reports and internal meddling of NGOs' day-to-day operations became common. ${ }^{119}$

What allowed the bureaucracy's dominance over civil society to continue? The government delivered on its promises pertaining to economic development, and in response, the Japanese citizenry regarded the progress made by the developmental state in a positive light. In other words, 
public trust in the bureaucracy further empowered its role in managing the Japanese economy and society, leaving the state's overbearing governance of the nonprofit sector to continue without challenge. ${ }^{120}$ Added to this "performance legitimacy" was Japan's long history of deference to the state. ${ }^{121}$ Japanese even has a self-deprecating phrase expressing a sense of reverence for the bureaucracy, kansonminpi (translated literally as "respectful bureaucracy, despiteful common people"). ${ }^{122}$ Keiko Hirata cites Confucianism's emphasis on social stability, preference of the larger group over individuals, and hierarchical organization of society as the cultural motive behind the Japanese people's deference to the state. This wariness of dissident opinions against the government reached its peak during the Cold War era, when many anti-government NGOs and individuals were alleged to be communist or radically left-wing. With Japan's winning streak of economic growth, and the preexisting Japanese tendency to follow the bureaucracy, the state's constant intervention in the nonprofit sector remained intact for most of the twentieth century.

Recent socioeconomic circumstances have changed the nature of statecivil society relations in Japan, hinting at the possibility of an unforeseen growth trajectory for the nonprofit sector. The fruits of the developmental state-more middle-class citizens, more wealth, and more educational opportunities - have stimulated the expansion of civil society in Japan. ${ }^{123}$ Likewise, globalization has also contributed to the inception of Japan's young civil society. The developmental state naturally felt pressure to meet in line with the standards of the developed world and international norms favoring the concept of civil society. ${ }^{124}$

The government's changing attitude toward the charitable sector grew after two major earthquakes in 1995 (Kobe) and 2011 (Tohoku). The Kobe earthquake - with 6500 dead and 75,000 buildings demolishedwas especially damaging, and the response telling. ${ }^{125}$ Despite heroic stories of volunteerism, the overall coordination among the state, civil society, and thousands of volunteers was disorganized, failing to respond to the disaster in an efficient manner. ${ }^{126}$ Stringent registration laws for nonprofit organizations prevented the government from seamlessly communicating with small-scale organizations that convened in Kobe. ${ }^{127}$ At the same time, petty internal power struggles within the bureaucracy aggravated the situation at hand. ${ }^{128}$ This administrative disaster, betraying the people's trust in the bureaucracy, served as an impetus for a series of regulatory and policy changes conducive to the growth of civil society. The 1998 NPO (nonprofit organization) Law eased requirements for registration, and in 
2002 the government began engaging academics and NGOs on discussing plans to reform the entire legal framework for civil society. ${ }^{129}$

Coupled with this renewed attitude of the government toward the nonprofit sector in the aftermath of the Kobe earthquake were changing social circumstances. Most significantly, the issue of Japan's aging society amidst a limited welfare state is creating new opportunities for NGOs, regarded by the government as a cost-effective alternative to provide essential social services to the elderly. ${ }^{130}$

In terms of individual giving, institutionalized philanthropy, and the nonprofit sector, Japan lags behind its regional counterparts in Asia. However, like many other Asian nations, Japan has committed acts of great charity over many centuries. Today, Japan shows that it, too, can be benevolent, and now has a political and social infrastructure evolving to facilitate the growth of the sector.

\section{SiNGAPORE}

Singapore tops the charts in many socioeconomic measurements. Singaporeans boast a GDP per capita of $\$ 52,888.70$, among the highest in the world. ${ }^{131}$ They also enjoy a high quality of living, with a life expectancy of 83 and adult literacy rate of 96.8 percent. ${ }^{132,133}$ Quality health care, education, and other social welfare benefits and programs are taken care of by the government. Where, in such a well-managed and tightly controlled landscape, is there room for philanthropic input? Much of the donated money goes abroad, and the aggregate number of donations is relatively low. ${ }^{134,135}$ In fact, one of the few major players in philanthropic giving in Singapore is the Tote Board, a government-backed organization. ${ }^{136}$ What input does come from the nonprofit sector is still heavily influenced by the state. The government's stance is generally adverse to NGOs, especially politically vocal ones. ${ }^{137}$ As the primary caretaker of social services, Singapore's government fundamentally defines the role of doing good in its modern nation-state.

It was not always so. From 1819 to 1963, Singapore was under British colonial rule, with occupation by the Japanese empire from 1942 to 1945. ${ }^{138}$ During this pre-independence era, civil society in Singapore was quite vibrant in the form of ethnic self-help organizations. ${ }^{139}$ As authoritarian as it may have been, the British colonial government did not impede the indigenous growth of these groups and may have in fact indirectly created the room for civil society's growth through subpar provision of 
social services. ${ }^{140,141}$ In the 1950s and 1960s, these groups contributed to Singapore's fight for independence. ${ }^{142}$ Other types of associations, such as trade unions, student groups, and the women's movement started to flourish during this period as well. ${ }^{143}$ Without the presence of an authoritarian government overtly adversarial to civil society and monopolizing the provision of welfare, pre-independence Singapore was able to experience a hint of nascent civil society.

After independence, the People's Action Party (PAP) led by Lee Kuan Yew reversed what could have been a continued sense of excitement around civil society. Two underlying beliefs framed the government's early contentious attitude toward civil society. First, the PAP believed that the public sphere in Singapore had been excessively politicized during the final few years of the colonial era, with groups and riots on ethnic and ideological lines interrupting social stability. ${ }^{144}$ Second, the utmost priority of the government's policy agenda back then was economic development. ${ }^{145}$ Successful accomplishment on this front was reflected in the government's efficient provision of public benefits, leaving no space and few opportunities for civil society groups. ${ }^{146}$ From the perspective of the PAP, a powerful centralized government, superseding other segments of society, was absolutely crucial to maintaining both the social and the economic well-being of the newborn city-state.

The PAP imposed legal and "extra-legal" limits on civil society. ${ }^{147}$ The Internal Security Act and the Societies Act were used to oppress any form of dissident voices and increase oversight of non-governmental entities. ${ }^{148,149}$ More significant were the PAP government's political strategies and institutional barriers used to control and co-opt civil society. The party sought to delineate the public debate surrounding civil society by alternatively naming it as "civic" society, focusing more on the "responsibilities" of the citizenry rather than its "rights." ${ }^{150}$ Having begun as a oneparty state that unilaterally provided social services, the PAP shrewdly evolved into a "competitive authoritarian" ${ }^{51}$ regime that still adhered to the principal belief of the government as the core of society, while allowing limited, state-controlled civil outreach.

When Goh Chok Tong became the country's second prime minister in 1990, he instilled a sense of hope among Singaporeans that Singapore may soon become a liberalized society. ${ }^{152}$ At that time, Brigadier-General George Yeo, minister for information and the arts, gave a speech incorporating a metaphor apt for the current circumstances surrounding civil society in Singapore. He acknowledged past government policies and attitudes as 
resembling a "banyan tree" that gave no room for civil society to grow, calling for a "pruning" of the tree (yet keeping the tree as the core of society). ${ }^{153}$

But after losing four seats to the opposition in the 1991 general election, the PAP realized a more liberalized stance toward civil society did not result in more votes. Going forward, PAP gave less emphasis to its renewed state-civil society relations. ${ }^{154}$ Nonetheless, the small step forward taken by the government tilted the vertical relationship toward an increased presence of civil society in Singapore. Voluntary welfare associations and SDOs were welcomed in a supplementary role; this was known as the "many helping hands" policy. ${ }^{155}$ Although the Singaporean government might not be open to the idea of civil society opposed to the state, it is willing to accept a civil society supplementing the "pruned banyan tree" state.

The "pruned banyan tree" vision of state-civil society relations in Singapore applies to present-day affairs in the country. Philanthropic giving and charity organizations are welcomed, if not encouraged. Through the National Volunteer \& Philanthropy Centre, for example, various nationwide giving events are hosted to encourage individual giving, and tax schemes are renewed to incentivize larger scale philanthropic gestures from the private sector. ${ }^{156,157}$ With this continued acceptance by the government of the philanthropic and charitable community, the city-state's private sector and culture of giving and helping others might be on a more positive track for the future.

\section{Hong Kong}

Hong Kong, like Singapore, is an Asian city-state whose history is primarily characterized by British colonialism and rapid economic development. But the story of Hong Kong's philanthropy and charity differs due to its proximity and unique historical ties to China. Hong Kong also has a less interventionist government, allowing its social delivery sector to take a much more prominent role than its Singaporean counterpart. The history of doing good in Hong Kong has been shaped by these three primary factors: British colonialism, Chinese influence, and a laissez-faire state.

In colonizing Hong Kong, the British Empire sought to provide its merchants with a physical port of access to China but not necessarily to spread Christianity nor to "civilize" the local population, as it had done in its other colonies. ${ }^{158}$ With this narrower goal in mind, the British colonial government limited its involvement in the day-to-day affairs of Hong 
Kong society. ${ }^{159}$ Such "positive non-interventionism" profoundly impacted the nonprofit community. ${ }^{160}$

The British government neglected to provide education and health care, leaving room for Hong Kong's first nonprofit groups to emerge. ${ }^{161}$ These organizations divided into two types, Christian-inspired missionary charities and Chinese clan-based associations. ${ }^{162,163}$ In pursuit of converting the local citizens to Christianity, missionaries ended up providing schools, hospitals, orphanages, and even elderly care facilities. Chinese clan-based associations, known as kaifong, mobilized neighborhoods for mutual aid to fill the void left by the "small" British colonial government. They built the Man Mo Temple, launched by a few wealthy members of the Chinese community, and the Tung Wah Hospital. ${ }^{164}$

Even under British rule, Hong Kong remained in China's sphere of influence. Major events experienced by the Mainland-whether for good or for bad-had ramifications for Hong Kong. The aforementioned kaifong clan-based associations are one example of China's influence, and the number of these groups proliferated as Chinese refugees poured into the city in the wake of China's civil war between the Communist Party and the Nationalist Party. ${ }^{165}$ The colonial government could not single-handedly tackle all of the social challenges and demands rising from this influx, increasing the need for NGOs' supplementary assistance. This period also saw the rise of tung heung wui ("same-village associations," in English), formed by people who wanted to help those hailing from the same place of origin in China. ${ }^{166}$ It is still quite common for donors from Hong Kong to provide charitable support for projects in their home villages despite having left those places generations ago. ${ }^{167}$

It was also during this time that several NGOs and philanthropic organizations now well known in Hong Kong society were established. The Hong Kong Council of Social Service, a network of NGOs, was founded in 1947 to help coordinate the activities of these proliferating self-help organizations, and the Hong Kong Jockey Club declared its commitment to donate its annual surpluses for philanthropy. ${ }^{168}$ Both organizations are key intermediaries in the industry of doing good in Hong Kong today.

Especially since the 1997 "handover," China's influence continues to shape Hong Kong's civil society. In recent years, the unique political relationship of "one country, two systems" has prompted the formation of more advocacy groups, both in opposition to and in support of the Chinese government. ${ }^{169,170}$ 
Both the British and the Chinese influence developed against a backdrop of a laissez-faire government. Modern-day Hong Kong is a special administrative region, a city-state commonly known for a vibrant private sector, low tax schemes, and detached government involvement in social services. The government's regulatory framework for NGOs is neutral, not interfering with the formal establishment of such organizations and at the same time, not incentivizing further beyond the provisions of the Inland Revenue Ordinance pertaining to tax exemption. ${ }^{171}$ Private options for any social needs are readily made available to the Hong Kong population.

Officially, Hong Kong relies on free-market principles when it comes to delivering public welfare, and it certainly does so in comparison to Singapore. That is, the government is clearly not the main provider of social services. Nevertheless, the Hong Kong government now is the single largest source of funding for NGOs, providing 28 percent of their operating budgets. ${ }^{172}$ This funding occurs in response to pressure to spend more on public welfare, in the wake of rapid economic development and persistent income inequality. ${ }^{173,174}$ Given its dedication to a non-interventionist free market, yet attending to the demands of its people, the Hong Kong government has contracted out to SDOs the primary role of providing social services. Hong Kong's state-civil society relationship is one of supplementary mutual dependence, where a rise in the state's indirect spending on social welfare increases the size of the voluntary sector as well. ${ }^{175}$ Budget cuts have the opposite effect, and with recent financial crises, the Hong Kong government has decreased its funding for SDOs. ${ }^{176}$ Competition for government funding within the sector has thus intensified, and fundraising has been identified by numerous organizations to be the most difficult current challenge. ${ }^{177}$

\section{THAILAND}

Three historical experiences have defined the modern-day landscape of Thailand's charity and philanthropy. First, religious giving-particularly in the context of Buddhism- has been and still is a major part of the nationwide philanthropic culture. Second, Thailand's unique position as the only country in Southeast Asia not colonized by either Europe or Japan has implications for its social sector. Third, Thailand's current domestic challenges, including multiple military coups and regime changes, have contributed to an extreme politicization of its civil society. The cumulative result of 
these historical events is a relatively recent emergence of the nonprofit sector and a leaning within the sector toward advocacy-oriented social movements. Only recently have socioeconomic trends, including income equality, begun to encourage development of SDOs and social enterprises.

For centuries, Buddhism has functioned as the philanthropic epicenter of Thailand. ${ }^{178}$ Individual giving to both the religious order, Sangha, and to those in need helped acquire merit and to meet the moral standards expected of a Buddhist. ${ }^{179}$ Thais have long placed water jars outside their homes for thirsty individuals, and strangers commonly found free housing and food from welcoming village residents. ${ }^{180}$ Buddhist temples used donations for providing education, elderly care, and health care to their local communities, and they still play a pivotal role for doing good in Thailand. ${ }^{181}$

Thailand's civil society has also been shaped by its independence, as the sole Asian kingdom never colonized by foreign empires in the nineteenth and early twentieth centuries. ${ }^{182}$ Britain and France agreed to leave the nation as a buffer between their Asian spheres of influence. Two monarchs during this period maneuvered to preserve the balance, engaging with as many foreign delegations as possible via trade treaties. The two kings also opened the country to foreign influences by sending Thai aristocrats abroad to European institutions. By 1940, Thailand boasted a welldeveloped infrastructure, including roads, canals, railways, shipyards, hospitals, and schools. ${ }^{183}$ This might have partially contributed to the relatively late inception of the nonprofit sector in Thailand during the later years of the twentieth century, which offered an opening for organized civil society organizations only after the democratic transition. ${ }^{184}$

A more telling legacy is that of a powerful bureaucratic and military elite in Bangkok. Discouraged by the deteriorating royal class, this new elite staged a coup in 1932, paving the grounds for Thailand's cycle of future military coups. ${ }^{185}$ Under control-conscious military rule, there was little room for Thailand's civil society to grow. During and after World War II, the government used the National Culture Act of 1942 and similar laws to control Chinese clan-based philanthropic associations, in the name of fighting communism from China. ${ }^{186}$ For much of the twentieth century, the authoritarian military state continued to view with suspicion any organized form of private interests.

Thailand's first major civilian resistance against military dominance occurred in 1973, when 500,000 students came to the streets of Bangkok to protest for democracy, eventually forcing the government leaders to 
leave the country. ${ }^{187}$ Though military rule returned afterwards, the student protests and the increasing number of NGOs forced the military to believe that it had to work together with civil society for its own survival. ${ }^{188}$ As a result, Thailand saw an increase in the expression of social demands and in the number of grassroots organizations during the 1980s. ${ }^{189}$ However, under the unstable seesawing back and forth between military regimes and civilian rule, civil society in Thailand became ever more politicized and advocacy-oriented. ${ }^{190,191,192}$

\section{INDONESIA}

Through its sheer size, abundance of natural resources, and rapidly growing population, Indonesia is elevating its macroeconomic status to a point where it is now a part of the four emerging "MINT" 193 economies, alongside Mexico, Nigeria, and Turkey. Beneath this economic growth, however, are alarming indicators of poverty: more than half of the population still lives on less than two dollars a day, 29 out of every 1000 children die before the age of five, and the maternal death rate remains stubbornly high. ${ }^{194}$ Indonesia has long had such disparities of wealth, and its social sector has sought to fill the gap. Charity and philanthropy in Indonesia has encountered much support in the process, along with various roadblocks, in keeping with the country's unique cultural background.

Religion, particularly Islam and its cultural customs, occupies a prominent place in the Indonesian context of doing good. With more than 85 percent of the country professing Islamic faith, ${ }^{195,196}$ zakat (almsgiving), alongside non-obligatory forms of charity, defines the nature of individual philanthropy in Indonesia. Almost all Muslim Indonesians fulfill their zakat duties annually, and more than 90 percent of individual giving in Indonesia is accounted by religious giving. ${ }^{197,198}$ Amid this prevalence of Islamic philanthropy, institutionalized collection and administration of zakat funds came to the fore, both from the public sector and from the private sector. In 1949, the Ministry of Religious Affairs was founded; it later adopted the role of managing zakat funds, and private collecting agencies known as Lazis (Lembaga Amil Zakat) followed suit. ${ }^{199,200,201}$

Christianity also plays a role. Though less than ten percent of the population practices Christianity, the religion's commitment to delivering social services (including emergency disaster relief, education, and health care) make it a notable contributor. So does its follower base of wealthy and/or ethnic Chinese Indonesians. ${ }^{202,203}$ 
The religious backdrop does not always promote a positive environment for social services. Under the authoritarian Suharto government, many religious impulses were steered toward containing communism and cracking down on dissident political voices. ${ }^{204,205}$ Also, giving donations to non-religious NGOs-even those for social services-is less commonplace, and donating to non-Islamic organizations is even shunned. ${ }^{206}$

Religious and nonreligious NGOs developed under Dutch colonial rule. ${ }^{207}$ The Dutch government intervened little in private matters related to zakat, unintentionally allowing for the emergence of Islamic associations. ${ }^{208,209,210,211}$ To the dismay of the Dutch empire, Indonesian civil society grew toward social consciousness and a sector-wide goal of fighting for independence. ${ }^{212,213,214}$ With its clear division of public and private spheres, the Dutch colonial government enabled a freer Islamic philanthropic life that led to the establishment of community organizations.

The charitable sector faced a less tolerant government in the New Order era (1965-1998) under General Suharto. Suharto suppressed any dissent, halting the growth of NGOs and other civil society organizations in the country. ${ }^{215,216} \mathrm{He}$ co-opted religious activities for his agenda, as noted above, and limited other functions. ${ }^{217,218}$ Hans Antlöv, Rustam Ibrahim, and Peter van Tuijl aptly summarize the position of civil society in the New Order era:

During more than three decades of authoritarian rule, civil society in Indonesia was seen as a part of the problem, not as the solution. Civil society was there to be controlled, not to be listened to or as a partner to work with. ${ }^{219}$

At best, alongside religious groups, only community development-focused NGOs-locally known as Lembaga Swadaya Masyarakat, meaning "selfreliant community development institution"-were recognized by the government as in line with its development activities and policies. ${ }^{220}$ The legacy of this predatory food chain between the public sector and the social sector resonates across the country to this day, where some Suhartoera laws are still applicable and readily made available should the government deem necessary in its intent to control civil society. ${ }^{221}$

In the final years of the Suharto regime, and following its fall in 1998, political democratization resulted in an increase in the number of NGOs from thousands to tens of thousands just by the end of $2003 .^{222,223,224}$ However, a wide array of current challenges and obstacles remains for the 
charitable and philanthropic sector in Indonesia. Indonesia lacks any major incentive for this sector, in that tax exemptions for NGOs are not provided; nor are tax deductions for individual donors. ${ }^{225,226}$ Charitable organizations rely heavily on foreign funding, given a lack of vibrant domestic philanthropy. ${ }^{227}$ And in the wake of the politicized struggles under the Suharto regime, distrust remains high between the private, public, and nonprofit sectors. ${ }^{228,229}$ These areas can be improved with efforts by all relevant stakeholders in Indonesian society, tackling its challenges with the combined efforts of NGOs, the government, and the private sector.

\section{Malaysia}

The Malaysian experience of philanthropy is history in the making. That is, with its semi-authoritarian regime and stiffly divided multiethnic populace, Malaysia did not see a vibrant third sector until recently. ${ }^{230,}{ }^{231}$ Several factors inhibited the birth and growth of active charity, while recent changes bring a hint of hope for a slowly developing field.

Malaysia's "semi-authoritarian" label reflects the mismatch between its official status as a democratic nation and its reality as a one-party state..$^{232,233}$ Based on repressive legislative measures, some would argue that Malaysia is simply authoritarian. ${ }^{234}$ Civil society has been particularly restrained by the 1960 Internal Security Act and the 1966 Societies Act, which permit detaining without trial and categorizes NGOs as "friendly" or "political." ${ }^{235,236}$ The government has also established its own social organizations, including the National Human Rights Commission and the Federation of Malaysian Consumer Organizations, to absorb the functions of social movements and NGOs. ${ }^{237}$

In sharp contrast to the Dutch Indonesian experience of separate private and public spheres of Islam, Malaysia's authoritarian reach influenced religious philanthropic life. The difference stems from a British colonial legacy, one that elevated the status of sultans at the expense of religious institutions. ${ }^{238}$ Such a co-optation of religious affairs continued to exist throughout the post-colonial period; even the administration and collection of zakat is singlehandedly managed by governmental religious councils. ${ }^{239}$ In such an unfavorable environment, it is surprising that some NGOs and civic activities exist at all.

An authoritarian state also complicated relationships among Malaysia's multiethnic populace. Federal discrimination and ensuing ethnic tensions encouraged segregation of philanthropic beneficiary groups and a fractured 
civil society. ${ }^{240,241}$ In particular, Elizabeth Cogswell finds in her survey of civil society that in Malaysia, Chinese help Chinese, Malays help Malays, and Indians help Indians. While charitable organizations might state in their charters that they serve without regard to ethnicity, in practice some focused on assisting their ethnic groups in response to the government's discriminatory policies. ${ }^{242}$ Sometimes, a given ethnic group would even refuse help from another due to historical tensions. ${ }^{243}$ Chinese Malaysians, seeing the preferential treatment of Malays, often donated in China to their villages and communities of origin, rather than to other fellow Malaysians in need of assistance. ${ }^{244}$

Despite these challenges, recent affairs in Malaysia attest to potential. With increased exposure to uncensored social media and the Internet, Malaysians are demanding more in terms of political liberalization. ${ }^{245}$ Such desire burst forth when the dominant United Malays National Organization party suffered a heavy defeat in the 2008 elections, leading for the first time to a united electoral front within civil society against the government regardless of ethnicity. ${ }^{246}$ The transition might not come easily, given the lack of political experience among now-elected social leaders. ${ }^{247}$ Nonetheless, if these new members of the government promote productive reforms, charity and philanthropy in Malaysia may grow faster than ever before.

\section{Notes}

1. Peng, Jianmei. China Charitable Giving Report. China Charity Information Center, Beijing, China, 2014, p. 25.

2. "India's Poverty Profile." The World Bank, 27 May 2016. Web. 19 Apr. 2017. http://www.worldbank.org/en/news/infographic/2016/05 /27/india-s-poverty-profile

3. Iyengar, Rishi. "India's Cash Crisis Left It with 11 Fewer Billionaires." CNN Money. Cable News Network, 7 Mar. 2017. Web. 20 Apr. 2017. http://money.cnn.com/2017/03/07/news/economy/ india-billionaires-hurun-rich-list-demonetisation/

4. Sundar, Pushpa. "Philanthropy in the Building of Modern India." Revealing Indian Philanthropy. Eds. Mathieu Cantegreil, Dweep Chanana, and Ruth Kattumuri. London, United Kingdom: Alliance Publishing Trust, 2013, 31-43. Web. 20 Apr. 2017. https://www.ubs. $\mathrm{com} /$ content/dam/ubs/global/wealth_management/philanthropy_ valuesbased_investments/indian-philanthrophy.pdf

5. Cantegreil, Mathieu, Dweep Chanana, and Ruth Kattumuri. "Understanding Giving in India." Revealing Indian Philanthropy. Eds. Mathieu Cantegreil, 
Dweep Chanana, and Ruth Kattumuri. London, United Kingdom: Alliance Publishing Trust, 2013, 20-30. Web. 20 Apr. 2017. https://www.ubs. com/content/dam/ubs/global/wealth_management/philanthropy_valuesbased_investments/indian-philanthrophy.pdf

6. Maple, Terrie, and Richard Harrison. India Giving: Insights into the Nature of Giving across India. Rep. New Delhi, India: Charities Aid Foundation India, 2012. Web. 20 Apr. 2017. http://cafindia.org/ images/CAF_India_launches_India_Giving_Report_2012.pdf. Recited from Cantegreil, Mathieu, Dweep Chanana, and Ruth Kattumuri. "Understanding Giving in India." Revealing Indian Philanthropy. Eds. Mathieu Cantegreil, Dweep Chanana, and Ruth Kattumuri. London, United Kingdom: Alliance Publishing Trust, 2013, 20-30. Web. 20 Apr. 2017. https://www.ubs.com/content/dam/ubs/global/wealth_management/philanthropy_valuesbased_investments/indian-philanthrophy. pdf

7. Viswanath, Priya, and Noshir Dadrawala. "Philanthropy and Equity: The Case of India.” (2004): 1-31. Harvard Global Equity Initiative, 1 June 2004. Web. 20 Apr. 2017. https://www.cbd.int/financial/charity/ india-phequity.pdf

8. Anderson, Leona. "Contextualizing Philanthropy in South Asia: A Textual Analysis of Sanskrit Sources." Philanthropy in the World's Traditions. Eds. Edward L. Queen II, Warren F. Ilchman, and Stanley N. Katz. N.p.: Indiana UP, 1998, 57-78. Print.

9. Sundar, Pushpa. "Philanthropy in the Building of Modern India." Revealing Indian Philanthropy. Eds. Mathieu Cantegreil, Dweep Chanana, and Ruth Kattumuri. London, United Kingdom: Alliance Publishing Trust, 2013, 31-43. Web. 20 Apr. 2017. https://www.ubs. com/content/dam/ubs/global/wealth_management/philanthropy_ valuesbased_investments/indian-philanthrophy.pdf

10. "India | Discussion | History." India Philanthropy Discussion | Coutts Million Dollar Donor Report. Coutts, n.d. Web. 20 Apr. 2017. http:// philanthropy.coutts.com/en/reports/2015/india/discussion.html

11. "Overview of Civil Society Organizations: India." (n.d.): n. pag. Civil Society Briefs. Asian Development Bank, June 2009. Web. 20 Apr. 2017. https://www.adb.org/sites/default/files/publication/28966/csb-ind. pdf

12. Sundar, Pushpa. "Philanthropy in the Building of Modern India." Revealing Indian Philanthropy. Ed. Mathieu Cantegreil, Dweep Chanana, and Ruth Kattumuri. London, United Kingdom: Alliance Publishing Trust, 2013, 31-43. Web. 20 Apr. 2017. https://www.ubs.com/content/dam/ubs/global/wealth_management/philanthropy_valuesbased_investments/indian-philanthrophy.pdf 
13. "Overview of Civil Society Organizations: India." (n.d.): n. pag. Civil Society Briefs. Asian Development Bank, June 2009. Web. 20 Apr. 2017. https:// www.adb.org/sites/default/files/publication/28966/csb-ind.pdf

14. Viswanath, Priya, and Noshir Dadrawala. "Philanthropy and Equity: The Case of India." (2004): 1-31. Harvard Global Equity Initiative, 1 June 2004. Web. 20 Apr. 2017. https://www.cbd.int/financial/charity/ india-phequity.pdf

15. Sundar, Pushpa. "Philanthropy in the Building of Modern India." Revealing Indian Philanthropy. Eds. Mathieu Cantegreil, Dweep Chanana, and Ruth Kattumuri. London, United Kingdom: Alliance Publishing Trust, 2013, 31-43. Web. 20 Apr. 2017. https://www.ubs. $\mathrm{com} / \mathrm{content} / \mathrm{dam} / \mathrm{ubs} / \mathrm{global} /$ wealth_management/philanthropy_ valuesbased_investments/indian-philanthrophy.pdf

16. Juergensmeyer, Mark, and Darrin M. McMahon. Philanthropy in the World's Traditions. Ed. Edward L. Queen II, Warren F. Ilchman, and Stanley N. Katz. N.p.: Indiana UP, 1998, 263-78. Print.

17. Quoted in R B Upadhyaya (1976) Social Responsibility of Business and the Trusteeship Theory of Mahatma Gandhi (Sterling Publishers, New Delhi) p vi. Recited from Sundar, Pushpa. "Philanthropy in the Building of Modern India." Revealing Indian Philanthropy. Eds. Mathieu Cantegreil, Dweep Chanana, and Ruth Kattumuri. London, United Kingdom: Alliance Publishing Trust, 2013, 31-43. Web. 20 Apr. 2017. https:// www.ubs.com/content/dam/ubs/global/wealth_management/philanthropy_valuesbased_investments/indian-philanthrophy.pdf

18. Harijan (newspaper) l Feb 1942. Recited from Sundar, Pushpa. "Philanthropy in the Building of Modern India." Revealing Indian Philanthropy. Eds. Mathieu Cantegreil, Dweep Chanana, and Ruth Kattumuri. London, United Kingdom: Alliance Publishing Trust, 2013, 31-43. Web. 20 Apr. 2017. https://www.ubs.com/content/dam/ubs/ global/wealth_management/philanthropy_valuesbased_investments/ indian-philanthrophy.pdf

19. Sundar, Pushpa. "Philanthropy in the Building of Modern India." Revealing Indian Philanthropy. Eds. Mathieu Cantegreil, Dweep Chanana, and Ruth Kattumuri. London, United Kingdom: Alliance Publishing Trust, 2013, 31-43. Web. 20 Apr. 2017. https://www.ubs. $\mathrm{com} /$ content/dam/ubs/global/wealth_management/philanthropy_ valuesbased_investments/indian-philanthrophy.pdf

20. Cantegreil, Mathieu, Dweep Chanana, and Ruth Kattumuri, eds. Revealing Indian Philanthropy. London, United Kingdom: Alliance Publishing Trust, 2013. Web. 20 Apr. 2017. https://www.ubs.com/ content/dam/ubs/global/wealth_management/philanthropy_valuesbased_investments/indian-philanthrophy.pdf 
21. "Overview of Civil Society Organizations: India." (n.d.): n. pag. Civil Society Briefs. Asian Development Bank, June 2009. Web. 20 Apr. 2017. https://www.adb.org/sites/default/files/publication/28966/csb-ind. pdf

22. Sundar, Pushpa. "Philanthropy in the Building of Modern India." Revealing Indian Philanthropy. Eds. Mathieu Cantegreil, Dweep Chanana, and Ruth Kattumuri. London, United Kingdom: Alliance Publishing Trust, 2013, 31-43. Web. 20 Apr. 2017. https://www.ubs. com/content/dam/ubs/global/wealth_management/philanthropy_ valuesbased_investments/indian-philanthrophy.pdf

23. Mohan, Sudha. "Role and Relevance of Civil Society Organisations." The Indian Journal of Political Science 63.2/3 (2002): 193-211. JSTOR. Web. 20 Apr. 2017. http://www.jstor.org/stable/10.2307/42753686? ref=search-gateway:c88fla7dle26e6da0350cd68lc7fd3e4

24. Sheth, Arpan, Dinkar Ayilavarapu, and Anant Bhagwati. India Philanthropy Report 2015: Accelerating the Next Philanthropic Wave. Rep. Bain \& Company, 21 Mar. 2015. Web. 20 Apr. 2017. http://www.bain. com/Images/BAIN_REPORT_India_Philanthropy_Report_2015.pdf

25. Sheth, Arpan, Dinkar Ayilavarapu, and Anant Bhagwati. India Philanthropy Report 2015: Accelerating the Next Philanthropic Wave. Rep. Bain \& Company, 21 Mar. 2015. Web. 20 Apr. 2017. http://www.bain. com/Images/BAIN_REPORT_India_Philanthropy_Report_2015.pdf

26. Sheth, Arpan, Deval Sanghavi, Anant Bhagwati, Srikrishnan Srinivasan, and Pakzan Dastoor. India Philanthropy Report 2017: The Individual Philanthropist's Path to Full Potential. Rep. Bain \& company and Dasra, 4 Mar. 2017. Web. 20 Apr. 2017. http://www.bain.com/Images/ REPORT_India_Philanthropy_2017.pdf

27. Bankoff, Greg. "Dangers to Going It Alone: Social Capital and the Origins of Community Resilience in the Philippines." Continuity and Change 22.02 (2007): 327-55. Web. 27 Mar. 2017.

28. Bankoff, Greg. "Dangers to Going It Alone: Social Capital and the Origins of Community Resilience in the Philippines." Continuity and Change 22.02 (2007): 327-55. Web. 27 Mar. 2017.

29. Velasco, Gisela. "Corporate Philanthropy in Asia: The Philippine Case: An Overview of East and Southeast Asian Philanthropy." Center on Philanthropy and Civil Society, n.d. Web. 27 Mar. 2017. http://www. philanthropy.org/publications/online_publications/asia.pdf

30. "Civil Society in the Philippines." (n.d.): n. pag. Civil Society Briefs. Asian Development Bank, Feb. 2013. Web. 27 Mar. 2017.

31. Bankoff, Greg. "Dangers to Going It Alone: Social capital and the Origins of Community Resilience in the Philippines." Continuity and Change, 22.02 (2007): 327-55. Web. 27 Mar. 2017. 
32. "Civil Society in the Philippines." (n.d.): n. pag. Civil Society Briefs. Asian Development Bank, Feb. 2013. Web. 27 Mar. 2017.

33. Ferrer, Miriam Coronel. "The Philippine State and Civil Society Discourse and Praxis." Korea Observer, 35.3 (2004): 535-71. Web. 27 Mar. 2017.

34. "Civil Society in the Philippines." (n.d.): n. pag. Civil Society Briefs. Asian Development Bank, Feb. 2013. Web. 27 Mar. 2017.

35. Ferrer, Miriam Coronel. "The Philippine State and Civil Society Discourse and Praxis." Korea Observer, 35.3 (2004): 535-71. Web. 27 Mar. 2017.

36. Bankoff, Greg. "Dangers to Going It Alone: Social capital and the Origins of Community Resilience in the Philippines." Continuity and Change, 22.02 (2007): 327-55. Web. 27 Mar. 2017.

37. "Civil Society in the Philippines." (n.d.): n. pag. Civil Society Briefs. Asian Development Bank, Feb. 2013. Web. 27 Mar. 2017.

38. Velasco, Gisela. "Corporate Philanthropy in Asia: The Philippine Case: An Overview of East and Southeast Asian Philanthropy." Center on Philanthropy and Civil Society, n.d. Web. 27 Mar. 2017. http://www. philanthropy.org/publications/online_publications/asia.pdf

39. Bankoff, Greg. "Dangers to Going It Alone: Social capital and the Origins of Community Resilience in the Philippines." Continuity and Change, 22.02 (2007): 327-55. Web. 27 Mar. 2017.

40. Eaton, Kent. "Restoration or Transformation? Trapos versus NGOs in the Democratization of the Philippines." The Journal of Asian Studies, 62.02 (2003): 469-96. Web.

41. "Civil Society in the Philippines." (n.d.): n. pag. Civil Society Briefs. Asian Development Bank, Feb. 2013. Web. 27 Mar. 2017.

42. Eaton, Kent. "Restoration or Transformation? Trapos versus NGOs in the Democratization of the Philippines." The Journal of Asian Studies, 62.02 (2003): 469-96. Web.

43. Magadia, José. "Contemporary Civil society in the Philippines." Southeast Asian Affairs (1999): 253-68. JSTOR. Web. 27 Mar. 2017. http:// www.jstor.org/stable/10.2307/27912230?ref=search-gateway:c5e3649 $35963 \mathrm{c} 99 \mathrm{ae} 235 \mathrm{~b} 5 \mathrm{ac} 9 \mathrm{bfd} 44 \mathrm{cb}$

44. Magadia, José. "Contemporary Civil Society in the Philippines." Southeast Asian Affairs (1999): 253-68. JSTOR. Web. 27 Mar. 2017. http:// www.jstor.org/stable/10.2307/27912230? ref=search-gateway:c5e3649 $35963 \mathrm{c} 99 \mathrm{ae} 235 \mathrm{~b} 5 \mathrm{ac} 9 \mathrm{bfd} 44 \mathrm{cb}$

45. "2016 Social Progress Index | Social Progress Imperative." Social Progress Imperative. Social Progress Imperative, n.d. Web. 27 Mar. 2017. http:// www.socialprogressimperative.org/global-index/\#performance/countries/spi/diml,dim2,dim3

46. "Table of Results: Corruption Perceptions Index 2015." Transparency International. Transparency International, n.d. Web. 27 Mar. 2017. http://www.transparency.org/cpi2015\#results-table 
47. Koo, Hagen. "Civil Society and Democracy in South Korea." The Good Society, 11.2 (2002): 40-45. JSTOR. Web. 10 Mar. 2017. http://www. jstor.org/stable/10.2307/20711071?ref=search-gateway:a3f5c24ae587 $4934 \mathrm{fdc} 5 \mathrm{fcf} 34 \mathrm{~d} 4 \mathrm{fee} 3 \mathrm{f}$

48. Kim, C. S. (1992). The Culture of Korean Industry, University of Arizona Press, Tucson. Recited from Bidet, Eric. "Explaining the Third Sector in South Korea." Voluntas: International Journal of Voluntary and Nonprofit Organizations, 13.2, Focus on Asia (2002): 131-47. JSTOR. Web. 10 Mar. 2017. http://www.jstor.org/stable/10.2307/27927772?ref=sea rch-gateway:272a6845e8d68a2e3f64lb3lf730665d

49. Koo, Jeong-Woo. "The Origins of the Public Sphere and Civil Society: Private Academies and Petitions in Korea, 1506-1800." Social Science History, 31.3 (2007): 381-409. JSTOR. Web. 10 Mar. 2017. http:// www.jstor.org/stable/10.2307/40267945? ref=search-gateway:5057ec4 2f7bl745llae5l3b459b7a38f

50. Koo, Jeong-Woo. "The Origins of the Public Sphere and Civil Society: Private Academies and Petitions in Korea, 1506-1800.” Social Science History, 31.3 (2007): 381-409. JSTOR. Web. 10 Mar. 2017. http:// www.jstor.org/stable/10.2307/40267945?ref=search-gateway:5057ec4 2f7bl74511ae513b459b7a38f

51. Koo, Jeong-Woo. "The Origins of the Public Sphere and Civil Society: Private Academies and Petitions in Korea, 1506-1800." Social Science History, 31.3 (2007): 381-409. JSTOR. Web. 10 Mar. 2017. http:// www.jstor.org/stable/10.2307/40267945?ref=search-gateway:5057ec4 2f7bl7451lae513b459b7a38f.

52. Kim, Ho-Ki. "The State and Civil Society in South Korea, 1987-1999: CIVIL Movements and Democratic Consolidation." Asian Perspective, 25.1, Special Issue in Commemoration of the 25th Anniversary of Asian Perpsective (2001): 229-48. JSTOR. Web. 10 Mar. 2017. http://www. jstor.org/stable/10.2307/42704305? ref=search-gateway:1fde29fbb6bd e5b4033ec8c0b297e6ce

53. Sohn, Yu Jean. "The Institutional Context of Korean Philanthropy and the Role of Government and (Quasi-) Community Foundations.” Diss. U of Southern California, 2014. Aug. 2014. Web. 15 Mar. 2017. https:// research.beautifulfund.org/wp-content/uploads/1/cfile 23 . uf.220734395428C8B5336645.pdf

54. Kim, Ho-Ki. "The State and Civil Society in South Korea, 1987-1999: Civil Movements and Democratic Consolidation." Asian Perspective, 25.1, Special Issue in Commemoration of the 25th Anniversary of Asian Perpsective (2001): 229-48. JSTOR. Web. 10 Mar. 2017. http://www. jstor.org/stable/10.2307/42704305?ref=search-gateway:1fde29fbb6bd e5b4033ec8c0b297e6ce 
55. Bidet, Eric. "Explaining the Third Sector in South Korea." Voluntas: International Journal of Voluntary and Nonprofit Organizations, 13.2, Focus on Asia (2002): 131-47. JSTOR. Web. 10 Mar. 2017. http:// www.jstor.org/stable/10.2307/27927772? ref=search-gateway:272a68 $45 \mathrm{e} 8 \mathrm{~d} 68 \mathrm{a} 2 \mathrm{e} 3 \mathrm{f} 64 \mathrm{lb} 31 \mathrm{f} 730665 \mathrm{~d}$

56. Koo, Hagen. "Civil Society and Democracy in South Korea." The Good Society, 11.2 (2002): 40-45. JSTOR. Web. 10 Mar. 2017. http://www. jstor.org/stable/10.2307/2071107l?ref=search-gateway:a3f5c24ae587 4934fdc5fcf34d4fee $3 \mathrm{f}$

57. Bidet, Eric. "Explaining the Third Sector in South Korea." Voluntas: International Journal of Voluntary and Nonprofit Organizations, 13.2, Focus on Asia (2002): 131-47. JSTOR. Web. 10 Mar. 2017. http:// www.jstor.org/stable/10.2307/27927772?ref=search-gateway:272a68 $45 \mathrm{e} 8 \mathrm{~d} 68 \mathrm{a} 2 \mathrm{e} 3 \mathrm{f} 641 \mathrm{~b} 31 \mathrm{f} 730665 \mathrm{~d}$

58. Kim, Inchoon and Changsoon Hwang. "Defining the Nonprofit Sector: South Korea." Working Papers of the Johns Hopkins Comparative Nonprofit Sector Project, No. 41. Blatimore: The Johns Hopkins Center for Civil Society Studies, 2002.

59. Kim, Ho-Ki. "The State and Civil Society in South Korea, 1987-1999: Civil Movements and Democratic Consolidation.” Asian Perspective, 25.1, Special Issue in Commemoration of the 25th Anniversary of Asian Perpsective (2001): 229-48. JSTOR. Web. 10 Mar. 2017. http://www. jstor.org/stable/10.2307/42704305?ref=search-gateway:1 fde29fbb6bd e5b4033ec8c0b297e6ce

60. Bruce Cumings, The Origins of the Korean War: Liberation and the Emergence of Separate Regimes, 1945-47 (Princeton, NJ: Princeton University Press, 1981). Recited from Kim, Ho-Ki. "The State and Civil Society in South Korea, 1987-1999: Civil Movements and Democratic Consolidation." Asian Perspective, 25.1, Special Issue in Commemoration of the 25th Anniversary of Asian Perpsective (2001): 229-48. JSTOR. Web. 10 Mar. 2017. http://www.jstor.org/stable/10.2307/42704305? ref=search-gateway:1fde29fbb6bde 5b4033ec8c0b297e6ce

61. Koo, Hagen. "Civil Society and Democracy in South Korea." The Good Society, 11.2 (2002): 40-45. JSTOR. Web. 10 Mar. 2017. http://www. jstor.org/stable/10.2307/2071107l?ref=search-gateway:a3f5c24ae587 4934fdc5fcf34d4fee $3 \mathrm{f}$

62. Bidet, Eric. "Explaining the Third Sector in South Korea." Voluntas: International Journal of Voluntary and Nonprofit Organizations, 13.2, Focus on Asia (2002): 131-47. JSTOR. Web. 10 Mar. 2017. http:// www.jstor.org/stable/10.2307/27927772?ref=search-gateway:272a68 45e8d68a2e3f64lb3lf730665d 
63. Sohn, Yu Jean. "The Institutional Context of Korean Philanthropy and the Role of Government and (Quasi-) Community Foundations.” Diss. U of Southern California, 2014. Aug. 2014. Web. 15 Mar. 2017. https:// research.beautifulfund.org/wp-content/uploads/1/cfile 23 . uf.220734395428C8B5336645.pdf

64. The Saemaul Undong Movement in the Republic of Korea: Sharing Knowledge on Community-driven Development. Manila, Philippines: Asian Development Bank, 2012. Asian Development Bank, 2012. Web. 23 Mar. 2017. https://www.adb.org/sites/default/files/publication/29881/ saemaul-undong-movement-korea.pdf

65. The Saemaul Undong Movement in the Republic of Korea: Sharing Knowledge on Community-driven Development. Manila, Philippines: Asian Development Bank, 2012. Asian Development Bank, 2012. Web. 23 Mar. 2017. https://www.adb.org/sites/default/files/publication/29881/ saemaul-undong-movement-korea.pdf

66. Kim, Ho-Ki. "The State and Civil Society in South Korea, 1987-1999: Civil Movements and Democratic Consolidation." Asian Perspective, 25.1, Special Issue in Commemoration of the 25th Anniversary of Asian Perpsective (2001): 229-48. JSTOR. Web. 10 Mar. 2017. http://www. jstor.org/stable/10.2307/42704305? ref=search-gateway: 1 fde29fbb6bd e5b4033ec8c0b297e6ce

67. Bidet, Eric. "Explaining the Third Sector in South Korea." Voluntas: International Journal of Voluntary and Nonprofit Organizations, 13.2. Focus on Asia (2002): 131-47. JSTOR. Web. 10 Mar. 2017. http:// www.jstor.org/stable/10.2307/27927772?ref=search-gateway:272a68 $45 \mathrm{e} 8 \mathrm{~d} 68 \mathrm{a} 2 \mathrm{e} 3 \mathrm{f} 64 \mathrm{lb} 31 \mathrm{f} 730665 \mathrm{~d}$

68. Sohn, Yu Jean. “The Institutional Context of Korean Philanthropy and the Role of Government and (Quasi-) Community Foundations." Diss. U of Southern California, 2014. Aug. 2014. Web. 15 Mar. 2017. https:// research.beautifulfund.org/wp-content/uploads/1/cfile 23 . uf.220734395428C8B5336645.pdf

69. "Introduction to Confucian Thought." Asia for Educators. Columbia University, n.d. Web. 8 Mar. 2017. http://afe.easia.columbia.edu/special/china_1000bce_confucius_intro.htm

70. United Nations Development Programme, Unleashing the Potential of Philanthropy in China, 2015, p. 8.

71. Fuller, Pierre. "China's Charitable Past." The New York Times. The New York Times, 28 Sep. 2010. Web. 13 July 2016. http://www. nytimes.com/2010/09/29/opinion/29iht-edfuller.html

72. Qin, Hui. “Understanding China's Third Sector (SSIR)." Trans. Chengpang Lee. Eds. Chengpang Lee. Stanford Social Innovation Review, 16 Feb. 2017. Web. 1 Mar. 2017. https://ssir.org/articles/ entry/understanding_chinas_third_sector 
73. Johnson, Ian. "The Death and Life of China's Civil Society." JSTOR [JSTOR]. American Political Science Association, Sep. 2003. Web. 1 Mar. 2017. www.jstor.org/stable/3688711

74. United Nations Development Programme, Unleashing the Potential of Philanthropy in China, 2015, p. 8.

75. Qin, Hui. "Understanding China's Third Sector (SSIR)." Trans. Chengpang Lee. Ed. Chengpang Lee. Stanford Social Innovation Review, 16 Feb. 2017. Web. I Mar. 2017. https://ssir.org/articles/entry/ understanding_chinas_third_sector

76. Zhuang, Ailing. "Building the Philanthropy Sector in China." Zhen Zheng De Wen Ti Jie Jue Zhe: She Hui Qi Ye Ru He Yong Chuang Xin Gai Bian Shi Jie $=$ The Real Problem Solvers. By Ruth A. Shapiro. Trans. Ran Liu. Beijing: Zhong Guo Ren Min Da Xue Chu Ban She, 2014. N. pag. Print.

77. Qin, Hui. "Understanding China's Third Sector (SSIR)." Trans. Chengpang Lee. Ed. Chengpang Lee. Stanford Social Innovation Review, 16 Feb. 2017. Web. I Mar. 2017. https://ssir.org/articles/entry/ understanding_chinas_third_sector

78. Wong, Sonia Man Lai. "Non-Governmental Organisations and Government in China: Enemies or Allies?" Governing Society in Contemporary China. Ed. Lijun Yang and Wei Shan. New Jersey: World Scientific, 2017, 70. Print.

79. Hong, Haolan, Michelle Phillips, Visqi He, and Jaime FlorCruz. "Red Cross China in Credibility Crisis." CNN. Cable News Network, 6 July 2011. Web. 8 Mar. 2017. http://edition.cnn.com/2011/WORLD/ asiapcf/07/06/china.redcross/

80. Sun, Yuanqing. "Donations to Dropped 90\% Due to Charity Trust Crisis." China Daily Europe. State Council Information Office, 26 Aug. 2011. Web. 8 Mar. 2017. http://europe.chinadaily.com.cn/china/201 108/26/content_13200166.htm

81. Witt, Michael A., and Gordon Redding. "China: Authoritarian Capitalism." The Oxford Handbook of Asian Business Systems. Eds. Michael A. Witt and Gordon Redding. Oxford, United Kingdom: Oxford UP, 2015, 23. Print.

82. "WVS Database." WVS Database. World Values Survey Association, n.d. Web. 8 Mar. 2017. http://www.worldvaluessurvey.org/WVSOnline.jsp

83. “《慈善法》来了, 公益的春天还会远吗?” 财新网. Ed. 和谦 徐. 财新网, 11 Mar. 2016. Web. 18 July 2016. http://topics.caixin.com/2016-0311/100918963.html

84. “慈善法如何“善法更善”: 8 大进步与 10 大期待.” 财新网. Ed. 帆 张. 财新 网, 9 Mar. 2016. Web. 18 July 2016. http://opinion.caixin.com/201603-09/100917992.html

85. United Nations Development Programme, Unleashing the Potential of Philanthropy in China, 2015, 21-22. 
86. Chin, Josh. "The Good-And Bad-About China's New Charity Law." The Wall Street Journal. Dow Jones. 16 Mar. 2016. Web. 13 July 2016.

87. Peng, Jianmei. China Charitable Giving Report. China Charity Information Center, Beijing, China, 2014, p. 25.

88. Feng, Xiaoming. China's Charitable Foundations: Development and Policy-Related Issues. Stanford Center for International Development Working Paper No. 485, 2013.

89. Peng, Jianmei. China Charitable Giving Report. China Charity Information Center, Beijing, China, 2014, p. 25.

90. China Charitable Giving Report 2014, http://china.cnr.cn/ ygxw/20150920/t20150920_519909785.shtml, and Liu, Zhongxiang Annual Report on China's Foundation Development. Beijing Social Sciences Academic Press, China, 2013.

91. Edmonds, Richard Louis, and Steven M. Goldstein. "Taiwan in the Twentieth Century: An Introduction." The China Quarterly, 165 (2001): n. pag. Web. 3 Apr. 2017.

92. Chu, R. L. "Charity and Altruistic Behaviour in Chinese Society." Bulletin of the Institute of Ethnology Academia Sinica, 75 (1993): 105-32. Web. 3 Apr. 2017. Recited from Pan, Chung-Dao. "Third Sector Organisations and Social Welfare: A Study of the Role of Social Service and Charitable Organisations in Taiwan." Aston University Ph.D Thesis (2007): 1-326. July 2007. Web. 3 Apr. 2017.

93. Ting, J. C. "Merit-Accumulation Behaviour in Cultural Context: An Example from Participants in Taiwan's Buddhist Tzu-Chi Association, with Implications for Cross-Cultural Studies on Helping Behaviour." Bulletin of the Institute of Ethnology Academia Sinica, 85 (1998): 113-77. Web. 3 Apr. 2017. Recited from Pan, Chung-Dao. "Third Sector Organisations and Social Welfare: A Study of the Role of Social Service and Charitable Organisations in Taiwan." Aston University Ph.D Thesis (2007): 1-326. July 2007. Web. 3 Apr. 2017.

94. Hsu, Elizabeth. "Apple Daily: Why Tzu Chi Is Sparking Resentment." Taiwan News, 6 Mar. 2015. Web. 9 Apr. 2017. http://www.taiwannews. com.tw/en/news/2698712

95. Pan, Chung-Dao. "Third Sector Organisations and Social Welfare: A Study of the Role of Social Service and Charitable Organisations in Taiwan." Aston University Ph.D Thesis (2007): 1-326. July 2007. Web. 3 Apr. 2017.

96. Hsiao, Hsin-Huang Michael. "Emerging Social Movements and the Rise of a Demanding Civil Society in Taiwan." The Australian Journal of Chinese Affairs, 24 (1990): 163-80. JSTOR. Web. 3 Apr. 2017. http:// www.jstor.org/stable/10.2307/2158893?ref=search-gateway:7c7dl55 $863 \mathrm{a} 7250 \mathrm{fbdcefe} 77680 \mathrm{e} 4223$ 
97. Hsiao, Hsin-Huang Michael. "Emerging Social Movements and the Rise of a Demanding Civil Society in Taiwan." The Australian Journal of Chinese Affairs, 24 (1990): 163-80. JSTOR. Web. 3 Apr. 2017. http:// www.jstor.org/stable/10.2307/2158893?ref=search-gateway:7c7dl 55 $863 \mathrm{a} 7250 \mathrm{fbdcefe} 77680 \mathrm{e} 4223$

98. Hsiao, Hsin-Huang Michael. "Emerging Social Movements and the Rise of a Demanding Civil Society in Taiwan." The Australian Journal of Chinese Affairs, 24 (1990): 163-80. JSTOR. Web. 3 Apr. 2017. http:// www.jstor.org/stable/10.2307/2158893?ref=search-gateway:7c7dl 55 $863 \mathrm{a} 7250 \mathrm{fbdcefe} 77680 \mathrm{e} 4223$

99. Hsiao, Hsin-Huang Michael. "Emerging Social Movements and the Rise of a Demanding Civil Society in Taiwan." The Australian Journal of Chinese Affairs, 24 (1990): 163-80. JSTOR. Web. 3 Apr. 2017. http:// www.jstor.org/stable/10.2307/2158893?ref=search-gateway:7c7dl55 $863 \mathrm{a} 7250 \mathrm{fbdcefe} 77680 \mathrm{e} 4223$

100. Hsiao, Hsin-Huang Michael. "Emerging Social Movements and the Rise of a Demanding Civil Society in Taiwan." The Australian Journal of Chinese Affairs, 24 (1990): 163-80. JSTOR. Web. 3 Apr. 2017. http:// www.jstor.org/stable/10.2307/2158893?ref=search-gateway:7c7dl55 $863 \mathrm{a} 7250 \mathrm{fbdcefe} 77680 \mathrm{e} 4223$

101. Jung, Jai Kwan. "Popular Mobilization and Democratization: A Comparative Study of South Korea and Taiwan." Korea Observer, 42.3 (2011): 377-411. Web. 3 Apr. 2017.

102. Jung, Jai Kwan. "Popular Mobilization and Democratization: A Comparative Study of South Korea and Taiwan." Korea Observer, 42.3 (2011): 377-411. Web. 3 Apr. 2017.

103. Tien, Hung-mao. "Taiwan's Evolution toward Democracy: A Historical Perspective." Taiwan: Beyond the Economic Miracle. Ed. Denis Fred Simon and Michael Y. M. Kau. Armonk, NY: M.E. Sharpe, 1997. N. pag. Print.

104. Hsu, Carolyn, Fang-Yu Chen, Jamie P. Horsley, and Rachel Stern. "The State of NGOs in China Today." Brookings. Brookings Institution, l Feb. 2017. Web. 3 Apr. 2017. https://www.brookings.edu/blog/upfront $/ 2016 / 12 / 15 /$ the-state-of-ngos-in-china-today/

105. Lee, Wei-chin. "Diplomatic Impetus and Altruistic Impulse: NGOs and the Expansion of Taiwan's International Space." Brookings. Brookings Institution, 28 July 2016. Web. 3 Apr. 2017. https://www.brookings. edu/opinions/diplomatic-impetus-and-altruistic-impulse-ngos-and-theexpansion-of-taiwans-international-space/

106. Statistical Yearbook of Interior. Ministry of the Interior, n.d. Web. 3 Apr. 2017. http://sowf.moi.gov.tw/stat/year/elist.htm\#4+Cooperative+\&+ Civil+Associations 
107. Hirata, Keiko. "Civil Society and NGOs in Japan." Civil Society in Japan: The Growing Role of NGOs in Tokyo's Aid and Development Policy. By Keiko Hirata. Basingstoke: Palgrave Macmillan, 2002, 8-49. Web. 2 May 2017. http://www.csun.edu/ kh246690/civil_society_chl.pdf

108. Kawashima, Nobuko. "The Emerging Voluntary Sector in Japan: Issues and Prospects." (1999): 1-48. London School of Economics and Political Science, Centre for Voluntary Organisation. Web. 2 May 2017. http:// eprints.lse.ac.uk/29095/1/IWP7nobuko.pdf

109. Amenomori, Takayoshi. "Defining the Nonprofit Sector: Japan." Working Papers of the John Hopkings Comparative Nonprofit Sector Project, No. 15. Ed. L. M. Salamon and H. K. Anheier. Baltimore: The Johns Hopkins Institute for Policy Studies, 1993. Web. 2 May 2017. http://ccss.jhu. edu/wp-content/uploads/downloads/2011/09/Japan_CNP_ WP15_1993.pdf

110. Amenomori, Takayoshi. "Defining the Nonprofit Sector: Japan." Working Papers of the John Hopkins Comparative Nonprofit Sector Project, No. 15. Ed. L. M. Salamon and H. K. Anheier. Baltimore: The Johns Hopkins Institute for Policy Studies, 1993. Web. 2 May 2017. http://ccss.jhu. edu/wp-content/uploads/downloads/2011/09/Japan_CNP_ WP15_1993.pdf

111. Yamamoto, Tadashi. "The Nonprofit Sector in Japan: Historical Evolution and Future Challenges." The Johns Hopkins Comparative Nonprofit Sector Project (1998): 84-105. Japan Center for International Exchange. The Johns Hopkins Institute for Policy Studies. Web. 2 May 2017. http:// www.jcie.org/researchpdfs/Role_Nonstate/6_Chapter\%205.pdf

112. Amenomori, Takayoshi. "Defining the Nonprofit Sector: Japan." Working Papers of the John Hopkins Comparative Nonprofit Sector Project, No. 15. Eds. L. M. Salamon and H. K. Anheier. Baltimore: The Johns Hopkins Institute for Policy Studies, 1993. Web. 2 May 2017. http://ccss.jhu. edu/wp-content/uploads/downloads/2011/09/Japan_CNP_ WP15_1993.pdf

113. Yamamoto, Tadashi. "The Nonprofit Sector in Japan: Historical Evolution and Future Challenges." The Johns Hopkins Comparative Nonprofit Sector Project (1998): 84-105. Japan Center for International Exchange. The Johns Hopkins Institute for Policy Studies. Web. 2 May 2017. http:// www.jcie.org/researchpdfs/Role_Nonstate/6_Chapter\%205.pdf

114. Amenomori, Takayoshi. "Defining the Nonprofit Sector: Japan." Working Papers of the John Hopkins Comparative Nonprofit Sector Project, No. 15. Ed. L. M. Salamon and H. K. Anheier. Baltimore: The Johns Hopkins Institute for Policy Studies, 1993. Web. 2 May 2017. http://ccss.jhu. edu/wp-content/uploads/downloads/2011/09/Japan_CNP_ WP15_1993.pdf 
115. Yamamoto, Tadashi. "The Nonprofit Sector in Japan: Historical Evolution and Future Challenges." The Johns Hopkins Comparative Nonprofit Sector Project (1998): 84-105. Japan Center for International Exchange. The Johns Hopkins Institute for Policy Studies. Web. 2 May 2017. http:// www.jcie.org/researchpdfs/Role_Nonstate/6_Chapter\%205.pdf

116. Amenomori, Takayoshi. "Defining the Nonprofit Sector: Japan." Working Papers of the John Hopkins Comparative Nonprofit Sector Project, No. 15. Ed. L. M. Salamon and H. K. Anheier. Baltimore: The Johns Hopkins Institute for Policy Studies, 1993. Web. 2 May 2017. http://ccss.jhu. edu/wp-content/uploads/downloads/2011/09/Japan_CNP_ WP15_1993.pdf

117. Kawashima, Nobuko. "The Emerging Voluntary Sector in Japan: Issues and Prospects." (1999): 1-48. London School of Economics and Political Science, Centre for Voluntary Organisation. Web. 2 May 2017. http:// eprints.lse.ac.uk/29095/1/IWP7nobuko.pdf

118. Pekkanen, Robert. "After the Developmental State: Civil Society in Japan." Journal of East Asian Studies, 4.3, SPECIAL ISSUE: After the Developmental State in East Asia? (2004): 363-88. JSTOR. Web. 2 May 2017. http://www.jstor.org/stable/10.2307/23417947?ref=search-gat eway:e128523bbc7e6d0ed972605e0f0a5b5 l

119. Kawashima, Nobuko. "The Emerging Voluntary Sector in Japan: Issues and Prospects." (1999): 1-48. London School of Economics and Political Science, Centre for Voluntary Organisation. Web. 2 May 2017. http:// eprints.lse.ac.uk/29095/1/IWP7nobuko.pdf

120. Hirata, Keiko. "Civil Society and NGOs in Japan." Civil Society in Japan: The Growing Role of NGOs in Tokyo's Aid and Development Policy. By Keiko Hirata. Basingstoke: Palgrave Macmillan, 2002, 8-49. Web. 2 May 2017. http://www.csun.edu/ kh246690/civil_society_chl.pdf

121. Hirata, Keiko. "Civil Society and NGOs in Japan." Civil Society in Japan: The Growing Role of NGOs in Tokyo's Aid and Development Policy. By Keiko Hirata. Basingstoke: Palgrave Macmillan, 2002, 8-49. Web. 2 May 2017. http://www.csun.edu/ kh246690/civil_society_chl.pdf

122. Hirata, Keiko. "Civil Society and NGOs in Japan." Civil Society in Japan: The Growing Role of NGOs in Tokyo's Aid and Development Policy. By Keiko Hirata. Basingstoke: Palgrave Macmillan, 2002, 8-49. Web. 2 May 2017. http://www.csun.edu/ kh246690/civil_society_chl.pdf

123. Pekkanen, Robert. "After the Developmental State: Civil Society in Japan." Journal of East Asian Studies, 4.3, SPECIAL ISSUE: After the Developmental State in East Asia? (2004): 363-88. JSTOR. Web. 2 May 2017. http://www.jstor.org/stable/10.2307/23417947?ref=search-gat eway:e128523bbc7e6d0ed972605e0f0a5b5l

124. Pekkanen, Robert. "After the Developmental State: Civil Society in Japan." Journal of East Asian Studies, 4.3, SPECIAL ISSUE: After the 
Developmental State in East Asia? (2004): 363-88. JSTOR. Web. 2 May 2017. http://www.jstor.org/stable/10.2307/23417947?ref=search-gat eway:e128523bbc7e6d0ed972605e0f0a5b51

125. Leng, Rachel. “Japan's Civil Society from Kobe to Tohoku: Impact of Policy Changes on Government-NGO Relationship and Effectiveness of Post-Disaster Relief." Electronic Journal of Contemporary Japanese Studies, 15.1 (2015): n. pag. 19 Apr. 2015. Web. 2 May 2017. http:// scholar.harvard.edu/files/rachel_leng/files-ejcjs_-_japans_civil_society_ from_kobe_to_tohoku_rachel_leng.pdf

126. Leng, Rachel. “Japan's Civil Society from Kobe to Tohoku: Impact of Policy Changes on Government-NGO Relationship and Effectiveness of Post-Disaster Relief." Electronic Journal of Contemporary Japanese Studies, 15.1 (2015): n. pag. 19 Apr. 2015. Web. 2 May 2017. http:// scholar.harvard.edu/files/rachel_leng/files-ejcjs_-_japans_civil_society_ from_kobe_to_tohoku_rachel_leng.pdf

127. Leng, Rachel. “Japan's Civil Society from Kobe to Tohoku: Impact of Policy Changes on Government-NGO Relationship and Effectiveness of Post-Disaster Relief." Electronic Journal of Contemporary Japanese Studies, 15.1 (2015): n. pag. 19 Apr. 2015. Web. 2 May 2017. http:// scholar.harvard.edu/files/rachel_leng/files-ejcjs_-_japans_civil_society_ from_kobe_to_tohoku_rachel_leng.pdf

128. Leng, Rachel. "Japan's Civil Society from Kobe to Tohoku: Impact of Policy Changes on Government-NGO Relationship and Effectiveness of Post-Disaster Relief." Electronic Journal of Contemporary Japanese Studies, 15.1 (2015): n. pag. 19 Apr. 2015. Web. 2 May 2017. http:// scholar.harvard.edu/files/rachel_leng/files-ejcjs_-_japans_civil_society_ from_kobe_to_tohoku_rachel_leng.pdf

129. Pekkanen, Robert. "After the Developmental State: Civil Society in Japan." Journal of East Asian Studies, 4.3, SPECIAL ISSUE: After the Developmental State in East Asia? (2004): 363-88. JSTOR. Web. 2 May 2017. http://www.jstor.org/stable/10.2307/23417947?ref=search-gat eway:e128523bbc7e6d0ed972605e0f0a5b51

130. Pekkanen, Robert. "After the Developmental State: Civil Society in Japan." Journal of East Asian Studies, 4.3, SPECIAL ISSUE: After the Developmental State in East Asia? (2004): 363-88. JSTOR. Web. 2 May 2017. http://www.jstor.org/stable/10.2307/23417947?ref=search-gat eway:e128523bbc7e6d0ed972605e0f0a5b51

131. "GDP per capita (current US\$)." The World Bank DataBank. The World Bank, n.d. Web. 19 Oct. 2016. http://data.worldbank.org/indicator/ NY.GDP.PCAP.CD

132. "Life Expectancy at Birth, Total (years)." The World Bank DataBank. The World Bank, n.d. Web. 19 Oct. 2016. http://data.worldbank.org/ indicator/SP.DYN.LE00.IN 
133. "Latest Data | Department of Statistics Singapore." Department of Statistics Singapore. Government of Singapore, n.d. Web. 19 Oct. 2016. http://www.singstat.gov.sg/statistics/latest-data

134. "Singapore Philanthropy Findings." Singapore Philanthropy Findings. Coutts, n.d. Web. 19 Oct. 2016. http://philanthropy.coutts.com/en/ reports/2015/singapore/findings.html

135. "Singapore Philanthropy Discussion." Singapore Philanthropy Discussion. Coutts, n.d. Web. 19 Oct. 2016. http://philanthropy.coutts.com/en/ reports/2015/singapore/discussion.html

136. "Singapore Philanthropy Discussion." Singapore Philanthropy Discussion. Coutts, n.d. Web. 19 Oct. 2016. http://philanthropy.coutts.com/en/ reports/2015/singapore/discussion.html

137. Chong, Terence. "Civil Society in Singapore: Popular Discourses and Concepts." Sojourn: Journal of Social Issues in Southeast Asia, 20.2, Democracy and Civil Society: NGO Politics in Singapore (2005): 273-301. JSTOR. Web. 15 May 2017. http://www.jstor.org/stable/10 $.2307 / 41308060$ ? ref=search-gateway:4ec2b7eaa9a02883058877fb265 $445 \mathrm{fe}$

138. Ho, Khai Leong. "Review: Singapore Civil Society and British Power by E. Kay Gillis." Sojourn: Journal of Social Issues in Southeast Asia, 21.2, Dynamics of the Local (2006): 271-74. JSTOR. Web. 15 May 2017. http://www.jstor.org/stable/10.2307/41308079? ref=search-gateway: be59c93dbb0f7c2f7f92fe4de9885fe5

139. Tay, Simon S. C. "Towards a Singaporean Civil Society." Southeast Asian Affairs (1998): 244-61. JSTOR. Web. 15 May 2017. http://www.jstor. org/stable/10.2307/27912207?ref=search-gateway:939d64bl48afad7 $2570745020 \mathrm{c} 95 \mathrm{ceb} 0$

140. Chong, Terence. "Civil Society in Singapore: Popular Discourses and Concepts." Sojourn: Journal of Social Issues in Southeast Asia, 20.2, Democracy and Civil Society: NGO Politics in Singapore (2005): 273-301. JSTOR. Web. 15 May 2017. http://www.jstor.org/stable/10 $.2307 / 41308060$ ? ref=search-gateway:4ec2b7eaa9a02883058877fb265 $445 \mathrm{fe}$

141. Tay, Simon S. C. "Towards a Singaporean Civil Society." Southeast Asian Affairs (1998): 244-61. JSTOR. Web. 15 May 2017. http://www.jstor. org/stable/10.2307/27912207? ref=search-gateway:939d64bl48afad7 $2570745020 \mathrm{c} 95 \mathrm{ceb} 0$

142. Chong, Terence. "Civil Society in Singapore: Popular Discourses and Concepts." Sojourn: Journal of Social Issues in Southeast Asia, 20.2, Democracy and Civil Society: NGO Politics in Singapore (2005): 273-301. JSTOR. Web. 15 May 2017. http://www.jstor.org/stable/10 $.2307 / 41308060$ ?ref=search-gateway:4ec2b7eaa9a02883058877fb265 $445 \mathrm{fe}$ 
143. Tay, Simon S. C. "Towards a Singaporean Civil Society." Southeast Asian Affairs (1998): 244-61. JSTOR. Web. 15 May 2017. http://www.jstor. org/stable/10.2307/27912207?ref=search-gateway:939d64bl48afad7 2570745020 c95ceb0

144. Ortmann, Stephan. "Political Change and Civil Society Coalitions in Singapore." Government and Opposition, 50.1 (2015): 119-39. Web.

145. Tay, Simon S. C. "Towards a Singaporean Civil Society." Southeast Asian Affairs (1998): 244-61. JSTOR. Web. 15 May 2017. http://www.jstor. org/stable/10.2307/27912207?ref=search-gateway:939d64bl48afad7 2570745020 c 95 ceb0

146. Tay, Simon S. C. "Towards a Singaporean Civil Society." Southeast Asian Affairs (1998): 244-61. JSTOR. Web. 15 May 2017. http://www.jstor. org/stable/10.2307/27912207?ref=search-gateway:939d64bl48afad7 2570745020 c95ceb0

147. Lee, Terence. "Gestural Politics: Civil Society in "New" Singapore." Sojourn: Journal of Social Issues in Southeast Asia, 20.2, Democracy and Civil Society: NGO Politics in Singapore (2005): 132-54. JSTOR. Web. 15 May 2017. http://www.jstor.org/stable/10.2307/41308055?ref=se arch-gateway:0c4lf47clb40c633d664338b56fefcf7

148. Ortmann, Stephan. "Political Change and Civil Society Coalitions in Singapore." Government and Opposition, 50.1 (2015): 119-39. Web.

149. Lee, Terence. "Gestural Politics: Civil Society in "New" Singapore." Sojourn: Journal of Social Issues in Southeast Asia, 20.2, Democracy and Civil Society: NGO Politics in Singapore (2005): 132-54. JSTOR. Web. 15 May 2017. http://www.jstor.org/stable/10.2307/41308055?ref=se arch-gateway:0c4lf47clb40c633d664338b56fefcf7

150. Lee, Terence. "Gestural Politics: Civil Society in 'New' Singapore." Sojourn: Journal of Social Issues in Southeast Asia, 20.2, Democracy and Civil Society: NGO Politics in Singapore (2005): 132-54. JSTOR. Web. 15 May 2017. http://www.jstor.org/stable/10.2307/41308055?ref=se arch-gateway:0c4lf47clb40c633d664338b56fefcf7

151. Ortmann, Stephan. "Political Change and Civil Society Coalitions in Singapore." Government and Opposition, 50.1 (2015): 119-39. Web.

152. Lee, Terence. "Gestural Politics: Civil Society in 'New' Singapore." Sojourn: Journal of Social Issues in Southeast Asia, 20.2, Democracy and Civil Society: NGO Politics in Singapore (2005): 132-54. JSTOR. Web. 15 May 2017. http://www.jstor.org/stable/10.2307/41308055?ref=se arch-gateway:0c4lf47clb40c633d664338b56fefcf7

153. Tay, Simon S. C. "Towards a Singaporean Civil Society." Southeast Asian Affairs (1998): 244-61. JSTOR. Web. 15 May 2017. http://www.jstor. org/stable/10.2307/27912207?ref=search-gateway:939d64bl48afad7 2570745020c95ceb0 
154. Tay, Simon S. C. "Towards a Singaporean Civil Society." Southeast Asian Affairs (1998): 244-61. JSTOR. Web. 15 May 2017. http://www.jstor. org/stable/10.2307/27912207?ref=search-gateway:939d64bl48afad7 $2570745020 \mathrm{c} 95 \mathrm{ceb} 0$

155. Tay, Simon S. C. "Towards a Singaporean Civil Society." Southeast Asian Affairs (1998): 244-61. JSTOR. Web. 15 May 2017. http://www.jstor. org/stable/10.2307/27912207?ref=search-gateway:939d64bl48afad7 $2570745020 \mathrm{c} 95 \mathrm{ceb} 0$

156. Chew, Hui Min. "Singapore Budget 2015: Tax Deduction of 200 per Cent the Amount Donated in Jubilee Year." The Straits Times. The Straits Times, 19 Jan. 2016. Web. 15 May 2017. http://www.straitstimes.com/ singapore/singapore-budget-2015-tax-deduction-of-300-per-cent-theamount-donated-in-jubilee-year

157. Goy, Priscilla. "Giving Week Gets 24\% More Donations in Its Latest Collection." The Straits Times. The Straits Times, 19 Jan. 2016. Web. 15 May 2017. http://www.straitstimes.com/singapore/giving-week-gets24-more-donations-in-its-latest-collection.

158. Fichtl, Eric. "An Introduction to the Third Sector in Hong Kong: Historical Developments and Current Outlook." (2006): 1-16. Web. 25 May 2017. http://www.ericfichtl.org/images/uploads/Fichtl_ ThirdSectorHongKong.pdf

159. "Content \& Overview." Study on the Third Sector Landscape in Hong Kong (2004): 1-37. Research Reports-Archives. Central Policy UnitThe Government of the Hong Kong Special Administrative Region, 27 Aug. 2004. Web. 25 May 2017. http://www.cpu.gov.hk/doc/en/ research-reports/3rd_content.pdf

160. Lam, Wai-Fung, and James L. Perry. "The Role of the Nonprofit Sector in Hong Kong's Development." Voluntas: International Journal of Voluntary and Nonprofit Organizations, 11.4 (2000): 355-73. JSTOR. Web. 25 May 2017. http://www.jstor.org/stable/10.2307/27927698? ref=search-gateway:c42424e81b95082f47d8a77c36ffeb0f

161. "Content \& Overview." Study on the Third Sector Landscape in Hong Kong (2004): 1-37. Research Reports-Archives. Central Policy UnitThe Government of the Hong Kong Special Administrative Region, 27 Aug. 2004. Web. 25 May 2017. http://www.cpu.gov.hk/doc/en/ research-reports/3rd_content.pdf

162. Fichtl, Eric. "An Introduction to the Third Sector in Hong Kong: Historical Developments and Current Outlook." (2006): 1-16. Web. 25 May 2017. http://www.ericfichtl.org/images/uploads/Fichtl_ ThirdSectorHongKong.pdf

163. "Content \& Overview." Study on the Third Sector Landscape in Hong Kong (2004): 1-37. Research Reports-Archives. Central Policy UnitThe Government of the Hong Kong Special Administrative Region, 
27 Aug. 2004. Web. 25 May 2017. http://www.cpu.gov.hk/doc/en/ research-reports/3rd_content.pdf

164. Fichtl, Eric. "An Introduction to the Third Sector in Hong Kong: Historical Developments and Current Outlook." (2006): 1-16. Web. 25 May 2017. http://www.ericfichtl.org/images/uploads/Fichtl_ ThirdSectorHongKong.pdf

165. "Content \& Overview." Study on the Third Sector Landscape in Hong Kong (2004): 1-37. Research Reports-Archives. Central Policy UnitThe Government of the Hong Kong Special Administrative Region, 27 Aug. 2004. Web. 25 May 2017. http://www.cpu.gov.hk/doc/en/ research-reports/3rd_content.pdf

166. "Content \& Overview." Study on the Third Sector Landscape in Hong Kong (2004): 1-37. Research Reports-Archives. Central Policy UnitThe Government of the Hong Kong Special Administrative Region, 27 Aug. 2004. Web. 25 May 2017. http://www.cpu.gov.hk/doc/en/ research-reports/3rd_content.pdf

167. "Hong Kong Philanthropy Findings." Hong Kong Philanthropy Findings. Coutts, n.d. Web. 19 Oct. 2016. http://philanthropy.coutts.com/en/ reports/2015/hong-kong/findings.html

168. Fichtl, Eric. "An Introduction to the Third Sector in Hong Kong: Historical Developments and Current Outlook." (2006): 1-16. Web. 25 May 2017. http://www.ericfichtl.org/images/uploads/Fichtl_ ThirdSectorHongKong.pdf

169. Lam, Wai-man, and Kay Chi-yan Lam. "China's United Front Work in Civil Society: The Case of Hong Kong." International Journal of China Studies, 4.3 (2013): 301-25. Web. 25 May 2017.

170. Hung, Ho-fung, and Iam-chong Ip. "Hong Kong's Democratic Movement and the Making of China's Offshore Civil Society." Asian Survey, 52.3 (2012): 504-27. JSTOR. Web. 25 May 2017. http://www. jstor.org/stable/10.1525/as.2012.52.3.504?ref=search-gateway:a3377 $4 \mathrm{~b} 6 \mathrm{e} 4 \mathrm{eb} 7 \mathrm{lf} 0 \mathrm{al} 1 \mathrm{~b} 50 \mathrm{cca} 88 \mathrm{~d} 2 \mathrm{ad} 4$

171. Lam, Wai-Fung, and James L. Perry. "The Role of the Nonprofit Sector in Hong Kong's Development." Voluntas: International Journal of Voluntary and Nonprofit Organizations, 11.4 (2000): 355-73. JSTOR. Web. 25 May 2017. http://www.jstor.org/stable/10.2307/27927698? ref=search-gateway:c42424e81b95082f47d8a77c36ffeb0f

172. Loh, Christine. "Alive and Well but Frustrated: Hong Kong's Civil Society." China Perspectives, 2.70 (2007): 40-45. JSTOR. Web. 25 May 2017. http://www.jstor.org/stable/10.2307/24053505?ref=search-gat eway:6edf9c50c962bb7551b555c32cdb4flf

173. Sing, Ming. "Economic Development, Civil Society and Democratization in Hong Kong." Journal of Contemporary Asia, 26.4 (1996): 482-504. Web. 25 May 2017. 
174. Chan, Ming K. "The Legacy of the British Administration of Hong Kong: A View from Hong Kong." The China Quarterly, 151 (1997): 567-82. JSTOR. Web. 25 May 2017. http://www.jstor.org/ stable/10.2307/655254? ref=search-gateway:fcla5427644c704230634 $78 \mathrm{ef} 3 \mathrm{dda} 75 \mathrm{f}$

175. Lam, Wai-Fung, and James L. Perry. "The Role of the Nonprofit Sector in Hong Kong's Development." Voluntas: International Journal of Voluntary and Nonprofit Organizations, 11.4 (2000): 355-73. JSTOR. Web. 25 May 2017. http://www.jstor.org/stable/10.2307/27927698? ref=search-gateway:c42424e81b95082f47d8a77c36ffeb0f

176. "Content \& Overview." Study on the Third Sector Landscape in Hong Kong (2004): 1-37. Research Reports-Archives. Central Policy UnitThe Government of the Hong Kong Special Administrative Region, 27 Aug. 2004. Web. 25 May 2017. http://www.cpu.gov.hk/doc/en/ research-reports/3rd_content.pdf

177. "Content \& Overview." Study on the Third Sector Landscape in Hong Kong (2004): 1-37. Research Reports-Archives. Central Policy UnitThe Government of the Hong Kong Special Administrative Region, 27 Aug. 2004. Web. 25 May 2017. http://www.cpu.gov.hk/doc/en/ research-reports/3rd_content.pdf

178. Pongsapich, Amara. "Politics of Civil Society." Southeast Asian Affairs (1999): 325-35. JSTOR. Web. 5 June 2017. http://www.jstor.org/stab le/10.2307/27912234?ref=search-gateway:80fe3a074409cea3al 24919 64379afef

179. Guruge, Ananda W. P., and G. D. Bond. "Generosity and Service in Theravada Buddhism." Philanthropy in the World's Traditions. Eds. Edward L. Queen II, Warren F. Ilchman, and Stanley N. Katz. N.p.: Indiana UP, 1998, 79-96. Print.

180. Strengthening Philanthropy in the Asia Pacific: An Agenda for ActionBackground Paper: Thailand. Rep. Asia Pacific Philanthropy Consortium, July 2001. Web. 5 June 2017. http://unpanl.un.org/instradoc/ groups/public/documents/APCITY/UNPAN005489.pdf

181. Strengthening Philanthropy in the Asia Pacific: An Agenda for ActionBackground Paper: Thailand. Rep. Asia Pacific Philanthropy Consortium, July 2001. Web. 5 June 2017. http://unpanl.un.org/instradoc/ groups/public/documents/APCITY/UNPAN005489.pdf

182. Ellington, John W., and Serene Chen. The Thailand Report: National Landscape, Current Challenges and Opportunities for Growth. Rep. Institute for Societal Leadership, Singapore Management University, n.d. Web. 5 June 2017. https://isl.smu.edu.sg/sites/default/files/isl_smu_ edu_sg/CIL/Thailand\%20CIR\%20\%28Final\%20Draft\%29.pdf

183. D. R. SarDesai, Southeast Asia: Past \& Present, Fifth Edition (Boulder, CO: Westview Press, 2003), 139. Recited from Ellington, John W., and 
Serene Chen. The Thailand Report: National Landscape, Current Challenges and Opportunities for Growth. Rep. Institute for Societal Leadership, Singapore Management University, n.d. Web. 5 June 2017. https://isl.smu.edu.sg/sites/default/files/isl_smu_edu_sg/CIL/ Thailand\%20CIR\%20\%28Final\%20Draft\%29.pdf

184. “Civil Society Briefs: Thailand.” (n.d.): n. pag. Civil Society Briefs. Asian Development Bank. Nov. 2011. Web. 5 June 2017. https://www.adb. org/sites/default/files/publication/29149/csb-tha.pdf

185. Ellington, John W., and Serene Chen. The Thailand Report: National Landscape, Current Challenges and Opportunities for Growth. Rep. Institute for Societal Leadership, Singapore Management University, n.d. Web. 5 June 2017. https://isl.smu.edu.sg/sites/default/files/isl_smu_ edu_sg/CIL/Thailand\%20CIR\%20\%28Final\%20Draft $\% 29 . p d f$

186. Pongsapich, Amara. "Politics of Civil Society." Southeast Asian Affairs (1999): 325-35. JSTOR. Web. 5 June 2017. http://www.jstor.org/stab le $/ 10.2307 / 27912234$ ? ref=search-gateway: $80 \mathrm{fe} 3 \mathrm{a} 074409$ cea3al 24919 64379afef

187. Pongsapich, Amara. "Politics of Civil Society." Southeast Asian Affairs (1999): 325-35. JSTOR. Web. 5 June 2017. http://www.jstor.org/stab le $/ 10.2307 / 27912234$ ? ref=search-gateway: $80 \mathrm{fe} 3 \mathrm{a} 074409$ cea3al 24919 64379afef

188. Pongsapich, Amara. "Politics of Civil Society." Southeast Asian Affairs (1999): 325-35. JSTOR. Web. 5 June 2017. http://www.jstor.org/stab le $/ 10.2307 / 27912234$ ? ref=search-gateway: $80 \mathrm{fe} 3 \mathrm{a} 074409$ cea3al 24919 64379afef

189. Pathmanand, Ukrist. "Globalization and Democratic Development in Thailand: The New Path of the Military, Private Sector, and Civil Society." Contemporary Southeast Asia, 23.1 (2001): 24-42. JSTOR. Web. 5 June 2017. http://www.jstor.org/stable/10.2307/25798526?ref=search-gat eway:80937643c2efd8fl49173e50elfb059e

190. “Civil Society Briefs: Thailand.” (n.d.): n. pag. Civil Society Briefs. Asian Development Bank. Nov. 2011. Web. 5 June 2017. https://www.adb. org/sites/default/files/publication/29149/csb-tha.pdf

191. Reflections on Thai Civil Society. Rep. KEPA-Service Centre for Development Cooperation. Dec. 2011. Web. 5 June 2017. https:// www.kepa.fi/tiedostot/reflections-on-thai-civil-society-2011.pdf

192. Pongsapich, Amara. "Politics of Civil Society." Southeast Asian Affairs (1999): 325-35. JSTOR. Web. 5 June 2017. http://www.jstor.org/stab le $/ 10.2307 / 27912234$ ? ref=search-gateway: $80 \mathrm{fe} 3 \mathrm{a} 074409$ cea3al 24919 64379afef

193. O’Neill, Jim. "Who You Calling a BRIC?” Bloomberg View. Bloomberg. 12 Nov. 2013. Web. 11 July 2017. https://www.bloomberg.com/view/ articles/2013-11-12/who-you-calling-a-bric- 
194. Ellington, John W. The Indonesia Report: National Landscape, Current Challenges and Opportunities for Growth. Rep. Institute for Societal Leadership, Singapore Management University, n.d. Web. 12 June 2017. http://isl.smu.edu.sg/sites/default/files/isl_smu_edu_sg/CIL/ Indonesia\%20CIR\%20\%208Final\%20Draft\%29.pdf

195. Osili, Una, and Çağla Ökten. "Giving in Indonesia: A Culture of Philanthropy Rooted in Islamic Tradition." The Palgrave Handbook of Global Philanthropy. Eds. Femida Handy and Pamala Wiepking. Basingstoke: Palgrave Macmillan, 2015, 388-403. Print.

196. Strengthening Philanthropy in the Asia Pacific: An Agenda for ActionBackground Paper: Indonesia. Rep. Asia Pacific Philanthropy Consortium, July 2001. Web. 12 June 2017. http://unpanl.un.org/intradoc/ groups/public/documents/apcity/unpan005484.pdf.

197. Osili, Una, and Çağla Ökten. "Giving in Indonesia: A Culture of Philanthropy Rooted in Islamic Tradition." The Palgrave Handbook of Global Philanthropy. Eds. Femida Handy and Pamala Wiepking. Basingstoke: Palgrave Macmillan, 2015, 388-403. Print.

198. Strengthening Philanthropy in the Asia Pacific: An Agenda for ActionBackground Paper: Indonesia. Rep. Asia Pacific Philanthropy Consortium, July 2001. Web. 12 June 2017. http://unpanl.un.org/intradoc/ groups/public/documents/apcity/unpan005484.pdf

199. Kloos, David. "Review: Faith and the State. A History of Islamic Philanthropy in Indonesia by Amelia Fauzia." Bijdragen Tot De TaalLand- En Volkenkunde, 170.4, Colonial Re-Collections: Memories, Objects, and Performances (2014): 576-79. JSTOR. Web. 12 June 2017. http://www.jstor.org/stable/10.2307/43817977? ref=search-gateway: 27lal39c5808db8c6a9014c0683e223b

200. Fauzia, Amelia. "Faith and the State: A History of Islamic Philanthropy in Indonesia." Thesis. The University of Melbourne. 2008. Web. 12 June 2017. http://minerva-access.unimelb.edu.au/bitstream/handle $/ 11343 / 35228 / 118527 \_$amelia\%20thesis.pdf?sequence $=1$

201. Osili, Una, and Çağla Ökten. "Giving in Indonesia: A Culture of Philanthropy Rooted in Islamic Tradition." The Palgrave Handbook of Global Philanthropy. Eds. Femida Handy and Pamala Wiepking. Basingstoke: Palgrave Macmillan, 2015, 388-403. Print.

202. Sakai, Minako. "Building a Partnership for Social Service Delivery in Indonesia: State and Faith-based Organisations." Australian Journal of Social Issues, 47.3 (2012): 373-88. ProQuest. Web. 12 June 2017.

203. Ellington, John W. The Indonesia Report: National Landscape, Current Challenges and Opportunities for Growth. Rep. Institute for Societal Leadership, Singapore Management University, n.d. Web. 12 June 2017. http://isl.smu.edu.sg/sites/default/files/isl_smu_edu_sg/CIL/ Indonesia\%20CIR\%20\%208Final\%20Draft $\% 29$.pdf 
204. Sakai, Minako. "Building a Partnership for Social Service Delivery in Indonesia: State and Faith-based Organisations." Australian Journal of Social Issues, 47.3 (2012): 373-88. ProQuest. Web. 12 June 2017.

205. Antlöv, Hans, Rustam Ibrahim, and Peter van Tuijl. NGO Governance and Accountability in Indonesia: Challenges in a Newly Democratizing Country. Publication. The International Center for Not-for-Profit Law. July 2005. Web. 12 June 2017. http://www.icnl.org/research/library/ files/Indonesia/Peter_NGO\%20accountability $\% 20 \mathrm{in} \% 20$ Indonesia $\% 20$ July\%2005\%20version.pdf

206. Sakai, Minako. "Building a Partnership for Social Service Delivery in Indonesia: State and Faith-based Organisations." Australian Journal of Social Issues, 47.3 (2012): 373-88. ProQuest. Web. 12 June 2017.

207. Ellington, John W. The Indonesia Report: National Landscape, Current Challenges and Opportunities for Growth. Rep. Institute for Societal Leadership, Singapore Management University, n.d. Web. 12 June 2017. http://isl.smu.edu.sg/sites/default/files/isl_smu_edu_sg/CIL/ Indonesia\%20CIR\%20\%208Final\%20Draft $\% 29$.pdf

208. Latief, Hilman. Rev. of Faith and the State: A History of Islamic Philanthropy in Indonesia. Brill's Southeast Asian Library, v. 1. By Amelia Fauzia. Pacific Affairs, 88.1 (2015): 231-33. ProQuest. Web. 12 June 2017.

209. Kloos, David. "Review: Faith and the State. A History of Islamic Philanthropy in Indonesia by Amelia Fauzia." Bijdragen Tot De TaalLand- En Volkenkunde, 170.4, Colonial Re-Collections: Memories, Objects, and Performances (2014): 576-79. JSTOR. Web. 12 June 2017. http://www.jstor.org/stable/10.2307/43817977?ref=search-gateway: 27lal39c5808db8c6a9014c0683e223b

210. Fauzia, Amelia. "Faith and the State: A History of Islamic Philanthropy in Indonesia." Thesis. The University of Melbourne. 2008. Web. 12 June 2017. http://minerva-access.unimelb.edu.au/bitstream/handle/11343/35228/118527_amelia\%20thesis.pdf?sequence=1

211. Osili, Una, and Çağla Ökten. "Giving in Indonesia: A Culture of Philanthropy Rooted in Islamic Tradition." The Palgrave Handbook of Global Philanthropy. Ed. Femida Handy and Pamala Wiepking. Basingstoke: Palgrave Macmillan, 2015, 388-403. Print.

212. Fuad, Muhammad. "Civil Society in Indonesia: The Potential and Limits of Muhammadiyah." Sojourn: Journal of Social Issues in Southeast Asia, 17.2 (2002): 133-63. JSTOR. Web. 12 June 2017. http://www.jstor. org/stable/10.2307/41057084?ref=search-gateway:12190cda0c195f4 $70 \mathrm{c} 043 \mathrm{af} 834 \mathrm{c} 803 \mathrm{f5}$

213. Ibrahim, Rustam. CIVICUS Civil Society Index Report for the Republic of Indonesia. Rep. Yappika, 2006. Web. 12 June 2017. http://www.civicus. org/media/CSI_Indonesia_Country_Report.pdf 
214. Antlöv, Hans, Rustam Ibrahim, and Peter van Tuijl. NGO Governance and Accountability in Indonesia: Challenges in a Newly Democratizing Country. Publication. The International Center for Not-for-Profit Law. July 2005. Web. 12 June 2017. http://www.icnl.org/research/library/ files/Indonesia/Peter_NGO\%20accountability\%20in\%20Indonesia\%20 July\%2005\%20version.pdf

215. Kimura, Ehito. "State, Society, and Society: The Case of Indonesia." Harvard Asia Pacific Review, 7.1 (2003): 50-53. ProQuest. Web. 12 June 2017.

216. Strengthening Philanthropy in the Asia Pacific: An Agenda for ActionBackground Paper: Indonesia. Rep. Asia Pacific Philanthropy Consortium. July 2001. Web. 12 June 2017. http://unpanl.un.org/intradoc/ groups/public/documents/apcity/unpan005484.pdf

217. Sakai, Minako. "Building a Partnership for Social Service Delivery in Indonesia: State and Faith-based Organisations." Australian Journal of Social Issues, 47.3 (2012): 373-88. ProQuest. Web. 12 June 2017.

218. Antlöv, Hans, Rustam Ibrahim, and Peter van Tuijl. NGO Governance and Accountability in Indonesia: Challenges in a Newly Democratizing Country. Publication. The International Center for Not-for-Profit Law. July 2005. Web. 12 June 2017. http://www.icnl.org/research/library/ files/Indonesia/Peter_NGO\%20accountability\%20in\%20Indonesia\%20 July\%2005\%20version.pdf

219. Antlöv, Hans, Rustam Ibrahim, and Peter van Tuijl. NGO Governance and Accountability in Indonesia: Challenges in a Newly Democratizing Country. Publication. The International Center for Not-for-Profit Law. July 2005. Web. 12 June 2017. http://www.icnl.org/research/library/ files/Indonesia/Peter_NGO\%20accountability $\% 20$ in\%20Indonesia $\% 20$ July\%2005\%20version.pdf

220. Antlöv, Hans, Rustam Ibrahim, and Peter van Tuijl. NGO Governance and Accountability in Indonesia: Challenges in a Newly Democratizing Country. Publication. The International Center for Not-for-Profit Law. July 2005. Web. 12 June 2017. http://www.icnl.org/research/library/ files/Indonesia/Peter_NGO\%20accountability\%20in\%20Indonesia\%20 July\%2005\%20version.pdf

221. Ellington, John W. The Indonesia Report: National Landscape, Current Challenges and Opportunities for Growth. Rep. Institute for Societal Leadership, Singapore Management University, n.d. Web. 12 June 2017. http://isl.smu.edu.sg/sites/default/files/isl_smu_edu_sg/CIL/ Indonesia\%20CIR\%20\%208Final\%20Draft\%29.pdf

222. Osili, Una, and Çağla Ökten. "Giving in Indonesia: A Culture of Philanthropy Rooted in Islamic Tradition." The Palgrave Handbook of Global Philanthropy. Eds. Femida Handy and Pamala Wiepking. Basingstoke: Palgrave Macmillan, 2015, 388-403. Print. 
223. Strengthening Philanthropy in the Asia Pacific: An Agenda for ActionBackground Paper: Indonesia. Rep. Asia Pacific Philanthropy Consortium, July 2001. Web. 12 June 2017. http://unpanl.un.org/intradoc/ groups/public/documents/apcity/unpan005484.pdf

224. Ibrahim, Rustam. CIVICUS Civil Society Index Report for the Republic of Indonesia. Rep. Yappika, 2006. Web. 12 June 2017. http://www.civicus. org/media/CSI_Indonesia_Country_Report.pdf

225. Ellington, John W. The Indonesia Report: National Landscape, Current Challenges and Opportunities for Growth. Rep. Institute for Societal Leadership, Singapore Management University, n.d. Web. 12 June 2017. http://isl.smu.edu.sg/sites/default/files/isl_smu_edu_sg/CIL/ Indonesia\%20CIR\%20\%208Final\%20Draft $\% 29$.pdf

226. Osili, Una, and Çağla Ökten. "Giving in Indonesia: A Culture of Philanthropy Rooted in Islamic Tradition." The Palgrave Handbook of Global Philanthropy. Eds. Femida Handy and Pamala Wiepking. Basingstoke: Palgrave Macmillan, 2015, 388-403. Print.

227. Osili, Una, and Çağla Ökten. "Giving in Indonesia: A Culture of Philanthropy Rooted in Islamic Tradition." The Palgrave Handbook of Global Philanthropy. Eds. Femida Handy and Pamala Wiepking. Basingstoke: Palgrave Macmillan, 2015, 388-403. Print.

228. Strengthening Philanthropy in the Asia Pacific: An Agenda for ActionBackground Paper: Indonesia. Rep. Asia Pacific Philanthropy Consortium. July 2001. Web. 12 June 2017. http://unpanl.un.org/intradoc/ groups/public/documents/apcity/unpan005484.pdf

229. Antlöv, Hans, Rustam Ibrahim, and Peter van Tuijl. NGO Governance and Accountability in Indonesia: Challenges in a Newly Democratizing Country. Publication. The International Center for Not-for-Profit Law. July 2005. Web. 12 June 2017. http://www.icnl.org/research/library/ files/Indonesia/Peter_NGO\%20accountability $\% 20 \mathrm{in} \% 20$ Indonesia $\% 20$ July\%2005\%20version.pdf

230. Hedman, Eva-Lotta E. "Contesting State and Civil Society: Southeast Asian Trajectories." Modern Asian Studies, 35.4 (2001): 921-51. JSTOR. Web. 10 July 2017. http://www.jstor.org/stable/10.2307/313196?ref=searchgateway:b64560a9575aebl9023ff5fb77cb6fcb

231. Cogswell, Elizabeth Agee. "Private Philanthropy in Multiethnic Malaysia." Macalester International 13th ser. 12.1 (2002): 105-21. Web. 10 July 2017. http://digitalcommons.macalester.edu/macintl/voll2/ iss $1 / 13$

232. Hedman, Eva-Lotta E. “Contesting State and Civil Society: Southeast Asian Trajectories." Modern Asian Studies, 35.4 (2001): 921-51. JSTOR. Web. 10 July 2017. http://www.jstor.org/stable/10.2307/313196?ref=searchgateway:b64560a9575aeb19023ff5fb77cb6fcb 
233. Hilton, Matthew. "The Consumer Movement and Civil Society in Malaysia." International Review of Social History, 52.3 (2007): 373-406. ProQuest. Web. 10 July 2017.

234. Hilton, Matthew. "The Consumer Movement and Civil Society in Malaysia." International Review of Social History, 52.3 (2007): 373-406. ProQuest. Web. 10 July 2017.

235. Hedman, Eva-Lotta E. "Contesting State and Civil Society: Southeast Asian Trajectories.” Modern Asian Studies, 35.4 (2001): 921-51. JSTOR. Web. 10 July 2017. http://www.jstor.org/stable/10.2307/313196?ref=search-gate way:b64560a9575aebl9023ff5fb77cb6fcb

236. Hilton, Matthew. "The Consumer Movement and Civil Society in Malaysia." International Review of Social History, 52.3 (2007): 373-406. ProQuest. Web. 10 July 2017.

237. Hilton, Matthew. "The Consumer Movement and Civil Society in Malaysia." International Review of Social History, 52.3 (2007): 373-406. ProQuest. Web. 10 July 2017.

238. Hedman, Eva-Lotta E. "Contesting State and Civil Society: Southeast Asian Trajectories.” Modern Asian Studies, 35.4 (2001): 921-51. JSTOR. Web. 10 July 2017. http://www.jstor.org/stable/10.2307/313196?ref=searchgateway:b64560a9575aeb19023ff5fb77cb6fcb

239. Cogswell, Elizabeth Agee. "Private Philanthropy in Multiethnic Malaysia." Macalester International 13th ser. 12.1 (2002): 105-21. Web. 10 July 2017. http://digitalcommons.macalester.edu/macintl/voll2/ iss $1 / 13$

240. Hedman, Eva-Lotta E. "Contesting State and Civil Society: Southeast Asian Trajectories.” Modern Asian Studies, 35.4 (2001): 921-51. JSTOR. Web. 10 July 2017. http://www.jstor.org/stable/10.2307/313196?ref=searchgateway:b64560a9575aeb19023ff5fb77cb6fcb

241. Cogswell, Elizabeth Agee. "Private Philanthropy in Multiethnic Malaysia." Macalester International 13th ser. 12.1 (2002): 105-21. Web. 10 July 2017. http://digitalcommons.macalester.edu/macintl/voll2/iss1/13

242. Cogswell, Elizabeth Agee. "Private Philanthropy in Multiethnic Malaysia." Macalester International 13th ser. 12.1 (2002): 105-21. Web. 10 July 2017. http://digitalcommons.macalester.edu/macintl/voll2/iss1/13

243. Cogswell, Elizabeth Agee. "Private Philanthropy in Multiethnic Malaysia." Macalester International 13th ser. 12.1 (2002): 105-21. Web. 10 July 2017. http://digitalcommons.macalester.edu/macintl/voll2/iss1/13

244. Cogswell, Elizabeth Agee. "Private Philanthropy in Multiethnic Malaysia." Macalester International 13th ser. 12.1 (2002): 105-21. Web. 10 July 2017. http://digitalcommons.macalester.edu/macintl/voll2/iss1/13

245. Weiss, Meredith L. "Edging Toward a New Politics in Malaysia: Civil Society at the Gate?" Asian Survey, 49.5 (2009): 741-58. 
JSTOR. Web. 10 July 2017. http://www.jstor.org/stable/10.1525/ as.2009.49.5.74l ? ref=search-gateway:c9610fle $926 f 25 f c 951$ babb7662 $2 \mathrm{aa} 30$

246. Weiss, Meredith L. "Edging Toward a New Politics in Malaysia: Civil Society at the Gate?" Asian Survey, 49.5 (2009):741-58. JSTOR. Web. 10 July 2017. http://www.jstor.org/stable/10.1525/as.2009.49.5.741? ref=search-gate way:c9610fle926f25fc951 babb76622aa30

247. Weiss, Meredith L. "Edging Toward a New Politics in Malaysia: Civil Society at the Gate?" Asian Survey, 49.5 (2009):741-58. JSTOR. Web. 10 July 2017. http://www.jstor.org/stable/10.1525/as.2009.49.5.741?ref=search-gate way:c9610fle $926 f 25 f c 951$ babb76622aa30

Open Access This chapter is licensed under the terms of the Creative Commons Attribution 4.0 International License (http://creativecommons.org/licenses/ by $/ 4.0 /$ ), which permits use, sharing, adaptation, distribution, and reproduction in any medium or format, as long as you give appropriate credit to the original author(s) and the source, provide a link to the Creative Commons license and indicate if changes were made.

The images or other third party material in this chapter are included in the chapter's Creative Commons license, unless indicated otherwise in a credit line to the material. If material is not included in the chapter's Creative Commons license and your intended use is not permitted by statutory regulation or exceeds the permitted use, you will need to obtain permission directly from the copyright holder.

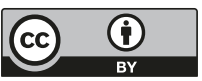

